\title{
Synergistic action of microwave-induced mild hyperthermia and paclitaxel in inducing apoptosis in the human breast cancer cell line MCF-7
}

\author{
SINA LIAO ${ }^{1}$, XIAOHUA HU ${ }^{2}$, ZHIHUI LIU ${ }^{1}$, YAN LIN $^{1}$, RONG LIANG $^{1}$, \\ YUMEI ZHANG ${ }^{1}$, QIAN LI ${ }^{1}$, YONGQIANG LI $^{1}$ and XIAOLI LIAO \\ ${ }^{1}$ Department of The First Chemotherapy, Affiliated Tumor Hospital of Guangxi Medical University; \\ ${ }^{2}$ Department of Medical Oncology, The First Affiliated Hospital of Guangxi Medical University, \\ Nanning, Guangxi 530021, P.R. China
}

Received December 1, 2017; Accepted October 15, 2018

DOI: $10.3892 / \mathrm{ol} .2018 .9629$

\begin{abstract}
Microwave mild hyperthermia and paclitaxel have been reported to be involved in variety of solid tumors. However, rare related researches have been accomplished via directly killing tumor cells using thermochemotherapy. In order to clarify the potential synergy between microwave-induced hyperthermia at temperatures $<41^{\circ} \mathrm{C}$ and paclitaxel chemotherapy for inhibiting the growth of the human breast cancer cell line MCF-7, an MTT assay was used. The MCF-7 cells cultured in vitro were treated with paclitaxel alone, treated with microwave-induced hyperthermia for $2 \mathrm{~h}$ alone (at $40,40.5$ or $41^{\circ} \mathrm{C}$ ), or treated with a combination of paclitaxel and $2 \mathrm{~h}$ of hyperthermia (at $40,40.5$ or $41^{\circ} \mathrm{C}$ ). Flow cytometry was used to determine the cell apoptosis rate and it was demonstrated that paclitaxel decreased cell viability in a dose-dependent manner. Alone, hyperthermia for $2 \mathrm{~h}$ at $41^{\circ} \mathrm{C}$ induced apoptosis in MCF-7 cells, to a greater extent compared with hyperthermia for $2 \mathrm{~h}$ at 40.0 or $40.5^{\circ} \mathrm{C}(\mathrm{P}<0.05)$. Together, paclitaxel and $2 \mathrm{~h}$ of hyperthermia at $40.5^{\circ} \mathrm{C}$ induced significantly increased apoptosis compared with either treatment alone $(\mathrm{P}<0.05)$. Increasing the temperature to $41^{\circ} \mathrm{C}$ in combination with paclitaxel increased the apoptotic ratio from $12.21 \pm 1.02 \%$ to $16.36 \pm 2.39 \%$. The apoptotic ratio correlated positively with hyperthermia temperature and duration following hyperthermia, as did the synergistic effect obtained by combining hyperthermia and paclitaxel. Notably, the combination of $5 \mu \mathrm{g} / \mathrm{ml}$ paclitaxel and $2 \mathrm{~h}$ of hyperthermia at $40^{\circ} \mathrm{C}$
\end{abstract}

Correspondence to: Professor Xiaoli Liao or Dr Yongqiang $\mathrm{Li}$, Department of The First Chemotherapy, Affiliated Tumor Hospital of Guangxi Medical University, 71 Hedi Road, Nanning, Guangxi 530021, P.R. China

E-mail:nllxl@163.com

E-mail: 1yq702702@126.com

Key words: microwave mild hyperthermia, paclitaxel, combined treatment, human breast cancer cell line MCF-7, apoptosis enhanced MCF-7 cell proliferation. Mild hyperthermia may exert anti-tumor effects by inducing apoptosis, and combining hyperthermia with paclitaxel synergistically induces apoptosis. Paclitaxel dose and hyperthermia temperature require careful optimization, as low-dose paclitaxel combined with hyperthermia at an insufficient temperature may enhance breast cancer proliferation.

\section{Introduction}

In 2015, 23,100 new cases of breast cancer were reported in the US alone, and the disease caused $>40,000$ mortalities, making it the second leading cause of cancer-associated mortality $(1,2)$. Anthracyclines are the anti-tumor drugs most commonly used to treat patients with breast cancer, yet $\leq 50 \%$ of patients respond effectively to them (3). Therefore, paclitaxel is frequently administered as supplementary chemotherapy, in order to increase the efficacy of anthracyclines. A meta-analysis study concluded that combining paclitaxel with anthracyclines leads to better overall survival of patients with metastatic breast cancer compared with either therapy alone (4). On the other hand, numerous studies suggest that paclitaxel may only be given following anthracyclines, due to the dose-dependent cardiotoxicity of anthracyclines (5-7), and that paclitaxel may cause febrile neutropenia in up to $32 \%$ of patients (4). Furthermore, studies suggest that paclitaxel is more effective against breast cancer when used in combination, compared with on its own. However, one study has suggested similar efficacy for paclitaxel monotherapy as for combination therapy involving doxorubicin, cyclophosphamide and 5-fluorouracil (8). Cumulative paclitaxel doses have been associated with notable toxic effects, including peripheral neurotoxicity, diarrhea and myalgia (9). Therefore, examining novel combinations of paclitaxel with other treatments against breast cancer is essential for enhancing therapeutic efficacy and reducing paclitaxel-associated toxicity.

A potential treatment that may be effective in combination with paclitaxel is exposure to mild hyperthermia, in which artificial heating methods are used in order to increase local- or whole-body temperatures to $39.5-42^{\circ} \mathrm{C}$. The resulting heating 
and its secondary effects may kill cancer cells directly, or induce apoptosis. Induced hyperthermia may selectively kill tumor cells without damaging normal tissues (10-14), and it may also sensitize cells to radio- and chemotherapy. Additionally, mild hyperthermia may reduce the toxic side effects of radioand chemotherapy through activation of the immune system, promoting the release of a large quantity of cytokines, and preserving hematopoiesis in the bone marrow (15-17).

The optimal temperature for mild hyperthermia is controversial. Previous studies suggest that the minimum temperature for hyperthermia alone or combined with radio- or chemotherapy is $41-43^{\circ} \mathrm{C}(18,19)$. Consistent with this, other studies have suggested that inducing hyperthermia at temperatures $<41^{\circ} \mathrm{C}$ inhibits tumor growth by activating the immune system, however it may not synergize with chemotherapy to kill tumor cells directly $(20,21)$. On the other hand, previous studies have reported that whole-body hyperthermia at temperatures of $\sim 39^{\circ} \mathrm{C}$ may synergize with chemotherapy (21).

The present study investigated whether paclitaxel and mild hyperthermia may synergize in order to inhibit the growth of the human breast cancer cell line MCF-7. In particular, the question of whether such synergy may occur at temperatures $<41^{\circ} \mathrm{C}$ was assessed.

\section{Materials and methods}

Cell culture, hyperthermia induction and treatment with paclitaxel. The human breast cancer cell line MCF-7 (Shanghai Institute of Biochemistry and Cell Biology, Shanghai, China) was cultured in standard cell culture plates containing RPMI 1640 medium (Invitrogen; Thermo Fisher Scientific, Inc., Waltham, MA, USA) supplemented with $10 \%$ fetal bovine serum (Invitrogen; Thermo Fisher Scientific, Inc., Waltham, $\mathrm{MA}, \mathrm{USA}$ ) at $37^{\circ} \mathrm{C}$ in an incubator with $5 \% \mathrm{CO}_{2}$ and saturated humidity. Cultures were maintained at $37^{\circ} \mathrm{C}$ (control), treated with paclitaxel alone, exposed to microwave-induced hyperthermia alone (at $40,40.5$ or $41^{\circ} \mathrm{C}$ ), or treated with the combination of paclitaxel and hyperthermia (at $40,40.5$ or $41^{\circ} \mathrm{C}$ ).

Hyperthermia was induced using a focused-beam microwave hyperthermia apparatus (UHR-2000; Huayuan Medical Equipment, Hunan, China) with an effective heating area $>16 \times 16 \times 5 \mathrm{~cm}^{3}$. The target temperature $\left(40,40.5\right.$ or $\left.41^{\circ} \mathrm{C}\right)$ was reached within $60 \mathrm{~min}$. Once the target temperature was reached, it was maintained for $2 \mathrm{~h}$. The overall temperature fluctuated within a range of $\pm 0.2^{\circ} \mathrm{C}$. Following hyperthermia, cultures were returned for 24 or $48 \mathrm{~h}$ to an incubator at $37^{\circ} \mathrm{C}$ with a $5 \% \mathrm{CO}_{2}$ atmosphere and saturated humidity.

For treatment with paclitaxel, cells were seeded into 96-well plates. When cell density reached $5 \times 10^{3} / \mathrm{ml}$, paclitaxel (Sigma-Aldrich; Merck KGaA, Darmstadt, Germany), was added at the indicated concentrations and cells were cultured for $24 \mathrm{~h}$.

MTT assay of cell proliferation. Cell proliferation following the different treatments was measured using the MTT Cell Proliferation Assay kit (Invitrogen; Thermo Fisher Scientific, Inc.). DMSO was used to dissolve the purple formazan. Absorbance was measured at $570 \mathrm{~nm}$ using Spectramax M2 microplate reader (Molecular Devices, LLC, Sunnyvale, CA, USA).
Apoptosis assay and determination of apoptotic ratio. At 24 and $48 \mathrm{~h}$ post-treatment, cultures were assayed for apoptosis using the Annexin V-fluorescein isothiocyanate (FITC)/propidium iodide (PI) apoptosis detection kit I (BD Biosciences, Franklin Lakes, NJ, USA). Cells were washed twice with $\mathrm{PBS}$, centrifuged $\left(78 \mathrm{x} \mathrm{g}\right.$ at $37^{\circ} \mathrm{C}$ for $\left.5 \mathrm{~min}\right)$ and incubated with Annexin V-FITC/PI at room temperature in the dark for 30 min. During flow cytometry with CytExpert software (version 2.0; Beckman Coulter, Inc., Brea, CA, USA), FITC was detected with excitation at $488 \mathrm{~nm}$ and emission at $530 \mathrm{~nm}$. Cells positive for Annexin V-FITC and negative for PI were defined as early apoptotic cells, while cells positive for Annexin V-FITC and PI were defined as late apoptotic cells. The ratios of cells in late to early apoptosis (apoptotic ratio) were calculated for each treatment group.

Statistical analysis. Data were analyzed using SPSS 16.0 (SPSS, Inc., Chicago, IL, USA). Continuous outcomes were expressed as the mean \pm standard deviation. Data were presented as bar charts, and inter-group differences were assessed for significance by one-way analysis of ANOVA with a Tukey's post hoc test. $\mathrm{P}<0.05$ was considered to indicate a statistically significant difference.

\section{Results}

Effects of mild hyperthermia on MCF-7 proliferation. At 24 and $48 \mathrm{~h}$ following hyperthermia at 40 and $40.5^{\circ} \mathrm{C}, \mathrm{MCF}-7$ cells displayed epithelial-cell-like adherent growth and obvious, gradual cell contours; cells were connected to one another in a uniform arrangement. They displayed no obvious morphological differences compared with the control group. By contrast, at 24 and $48 \mathrm{~h}$ after hyperthermia at $41^{\circ} \mathrm{C}$, a proportion of MCF-7 cells shrank and became rounded, with decreased transparency and loose intercellular connections. However, the majority of cells still displayed epithelial-cell-like adherent growth, vague contours, intercellular connections and an overall healthy appearance. A small number of cells appeared to undergo morphological alterations consistent with apoptosis (Fig. 1).

Effects of mild hyperthermia on MCF-7 apoptotic ratio. Previous studies have reported that mild hyperthermia at $41^{\circ} \mathrm{C}$ does not synergize with chemotherapy to kill tumor cells directly; instead, it exerts its anti-tumor effects by regulating the immune system. In the present study, the hypothesis that mild hyperthermia at temperatures $<41^{\circ} \mathrm{C}$ may induce anti-tumor effects by inducing apoptosis was tested. Therefore, cultures were exposed to hyperthermia at varying temperatures and the apoptotic ratios measured using flow cytometry. The apoptotic ratio was significantly higher following hyperthermia at $41^{\circ} \mathrm{C}$ compared with the control incubation at $37^{\circ} \mathrm{C}$. The apoptotic ratio significantly increased from $6.11 \pm 0.45 \%$ at $24 \mathrm{~h}$ following hyperthermia, to $11.38 \pm 1.75 \%$ at $48 \mathrm{~h}$ following hyperthermia $(\mathrm{P}<0.01)$. The apoptosis ratio was also significantly higher at $48 \mathrm{~h}$ at $41^{\circ} \mathrm{C}$ compared with 40 or $40.5^{\circ} \mathrm{C}(\mathrm{P}<0.05$; Fig. 2$)$. These results demonstrate that microwave-induced hyperthermia for $2 \mathrm{~h}$ at $41^{\circ} \mathrm{C}$ alone may induce apoptosis in MCF-7 cells at $24 \mathrm{~h}$ later. Apoptosis was increased when hyperthermia involved higher temperatures, or when cultures were examined at later time points following hyperthermia. 
A

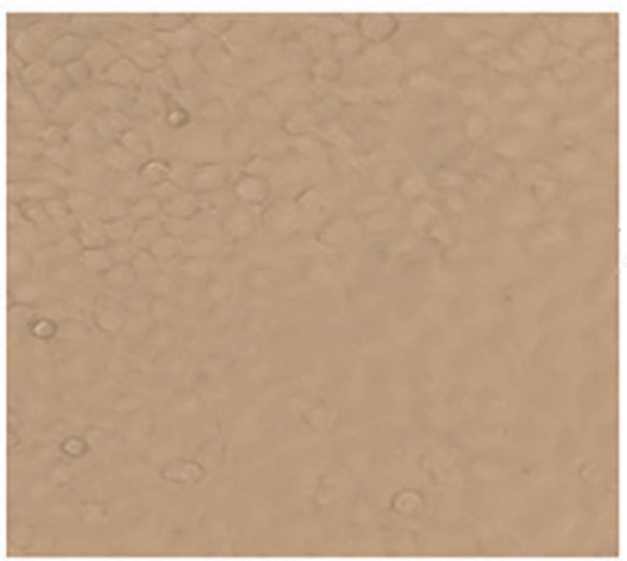

$37^{\circ} \mathrm{C}$

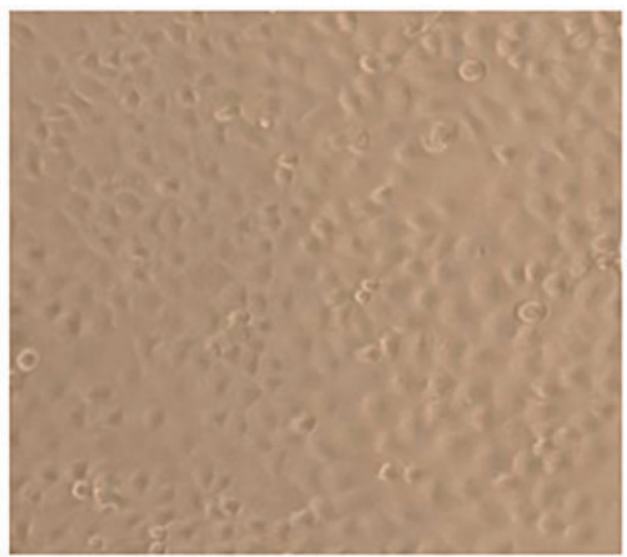

$40^{\circ} \mathrm{C}$

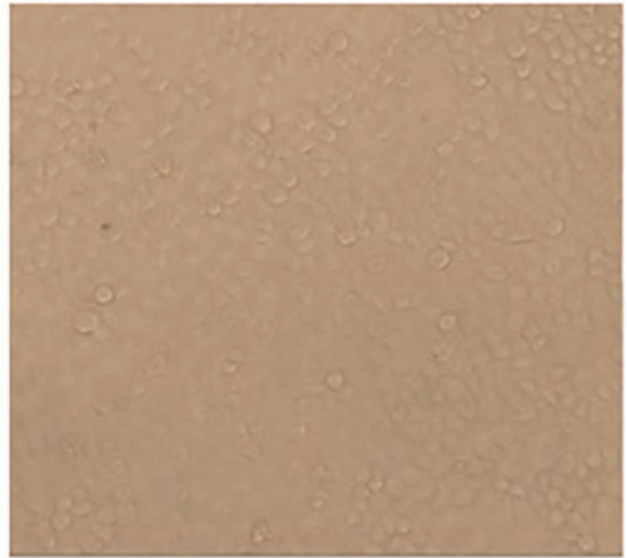

$40.5^{\circ} \mathrm{C}$

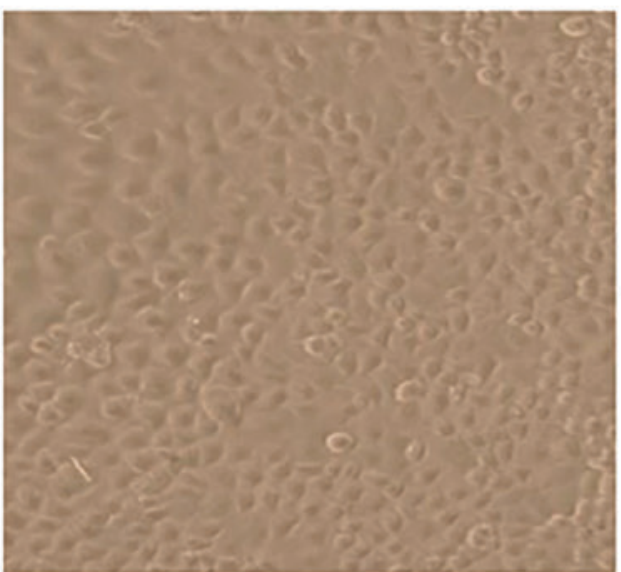

B

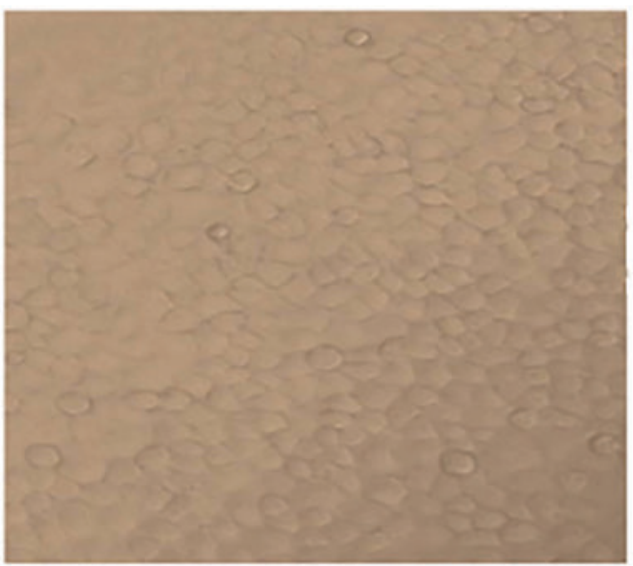

$37^{\circ} \mathrm{C}$

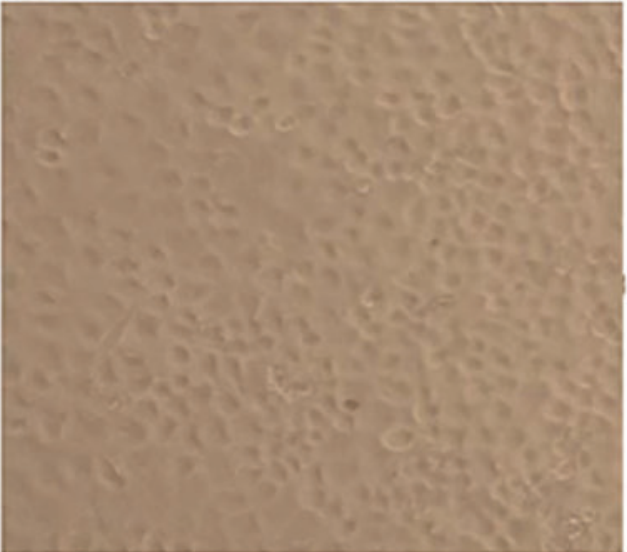

$40^{\circ} \mathrm{C}$

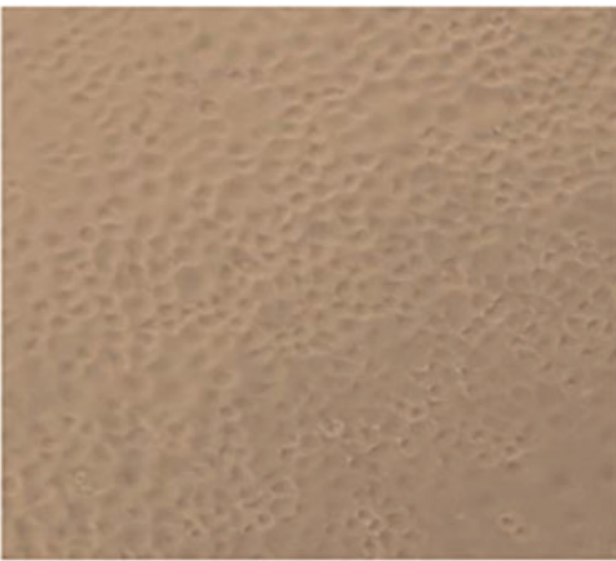

$40.5^{\circ} \mathrm{C}$

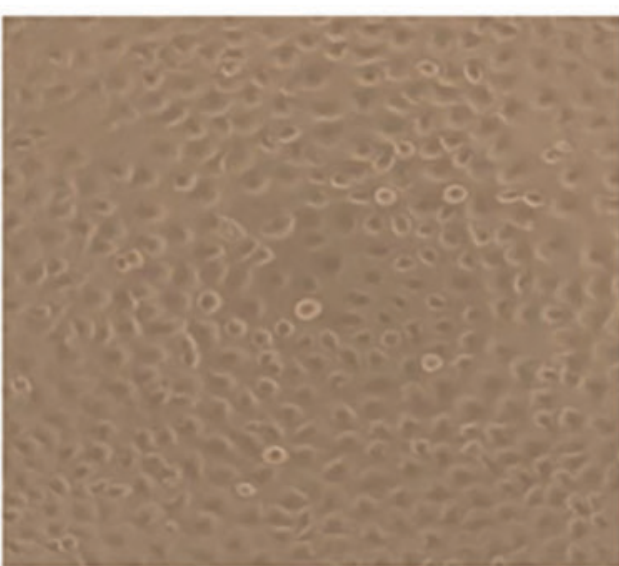

Figure 1. Photomicrographs displaying the effects of mild hyperthermia $\left(37^{\circ} \mathrm{C}, 40^{\circ} \mathrm{C}, 40.5^{\circ} \mathrm{C}\right.$ and $\left.41^{\circ} \mathrm{C}\right)$ on $\mathrm{MCF}-7$ growth at (A) $24 \mathrm{~h}$ post-exposure or (B) $48 \mathrm{~h}$ post-exposure. Obvious apoptotic cell morphology was observed at $48 \mathrm{~h}$ following hyperthermia at $41^{\circ} \mathrm{C}$. Magnification, $\mathrm{x} 100$ 

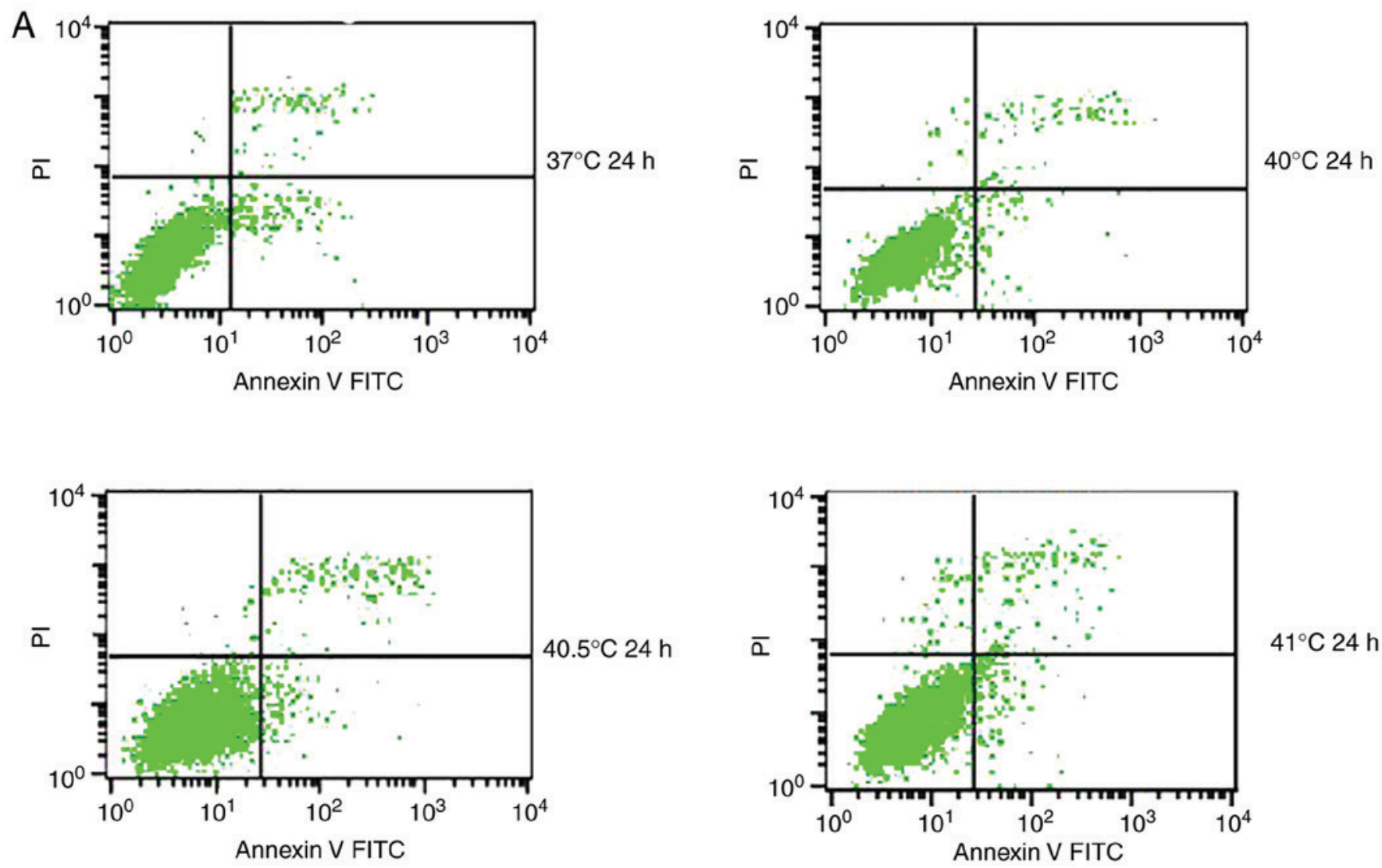

$41^{\circ} \mathrm{C} 24 \mathrm{~h}$
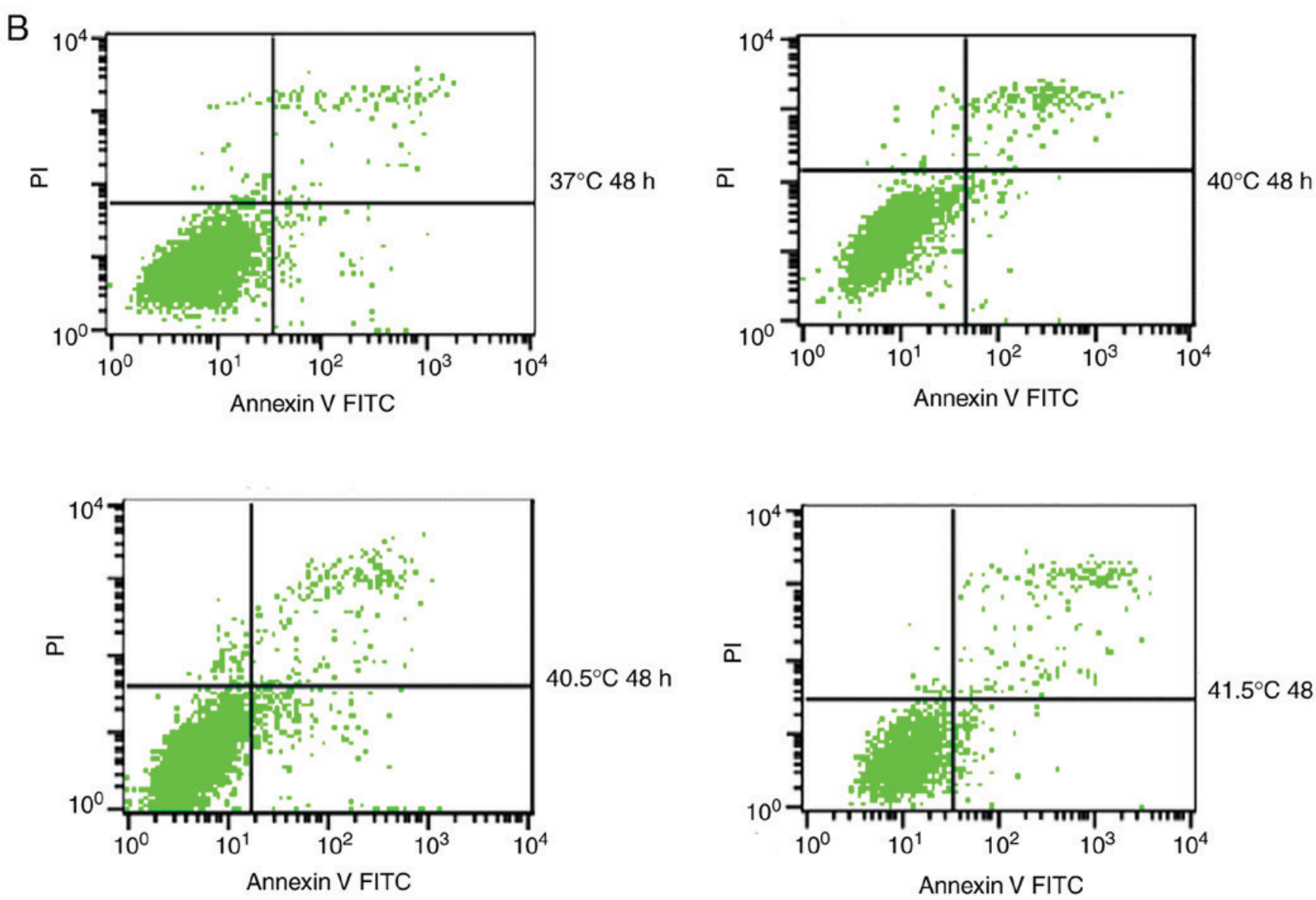

Figure 2. Effects of mild hyperthermia on the apoptotic ratio of MCF-7 cells. Flow cytometry of MCF-7 cells using an Annexin V-FITC/PI cell apoptosis staining kit. (A) $24 \mathrm{~h}$ following hyperthermia or (B) $48 \mathrm{~h}$ following hyperthermia. 

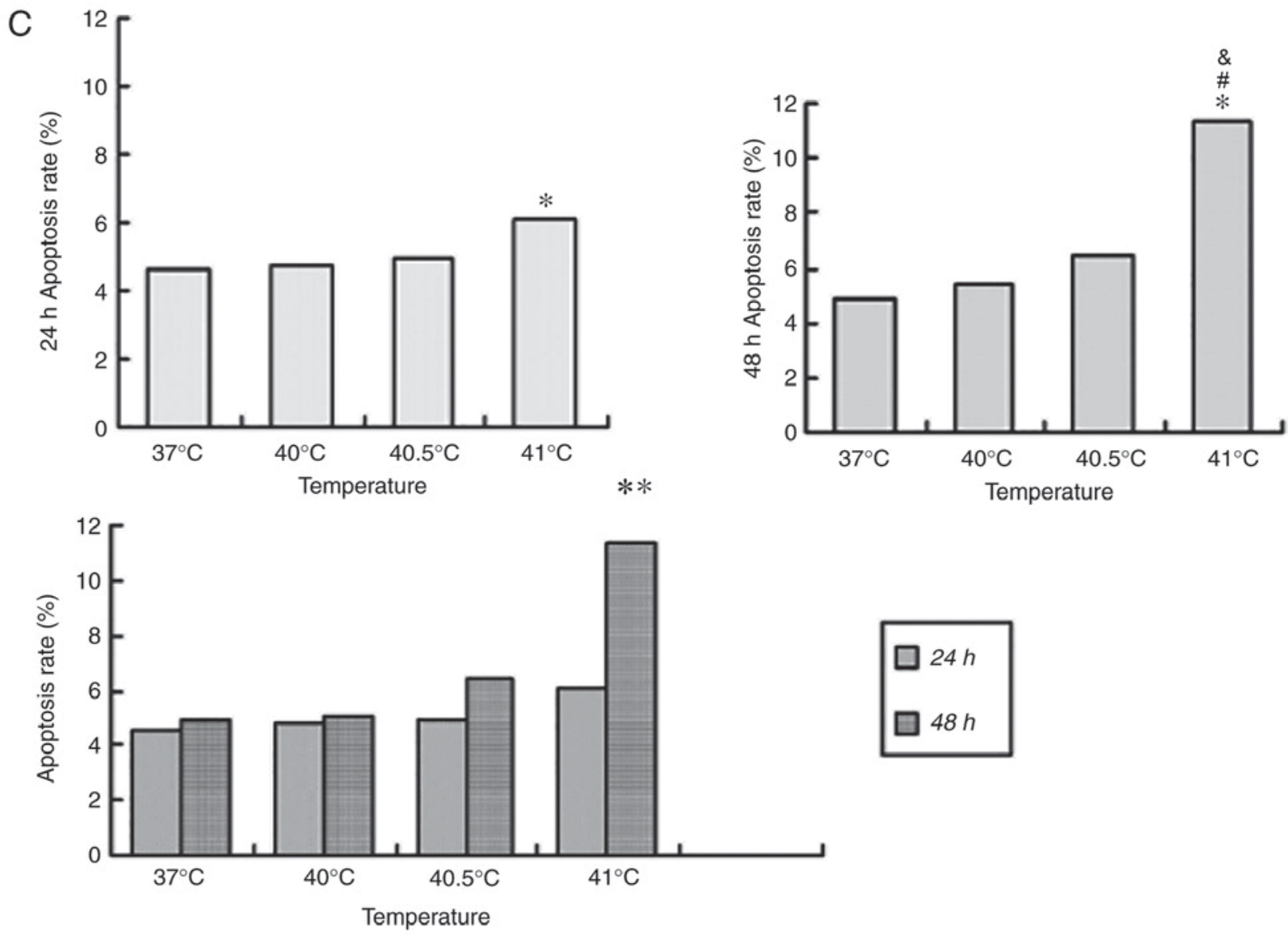

Figure 2. Continued. (C) The apoptotic ratio (\% apoptotic cells) 24 and $48 \mathrm{~h}$ following hyperthermia. ${ }^{* *} \mathrm{P}<0.01 \mathrm{vs} .48 \mathrm{~h}\left(41^{\circ} \mathrm{C}\right)$; ${ }^{*} \mathrm{P}<0.05$ vs. control group $\left(37^{\circ} \mathrm{C}\right)$; ${ }^{\#} \mathrm{P}<0.05$ vs. $40.5^{\circ} \mathrm{C}$; ${ }^{\&} \mathrm{P}<0.05$ vs. $40^{\circ} \mathrm{C}$. FITC, fluorescein isothiocyanate; PI, propidium iodide.

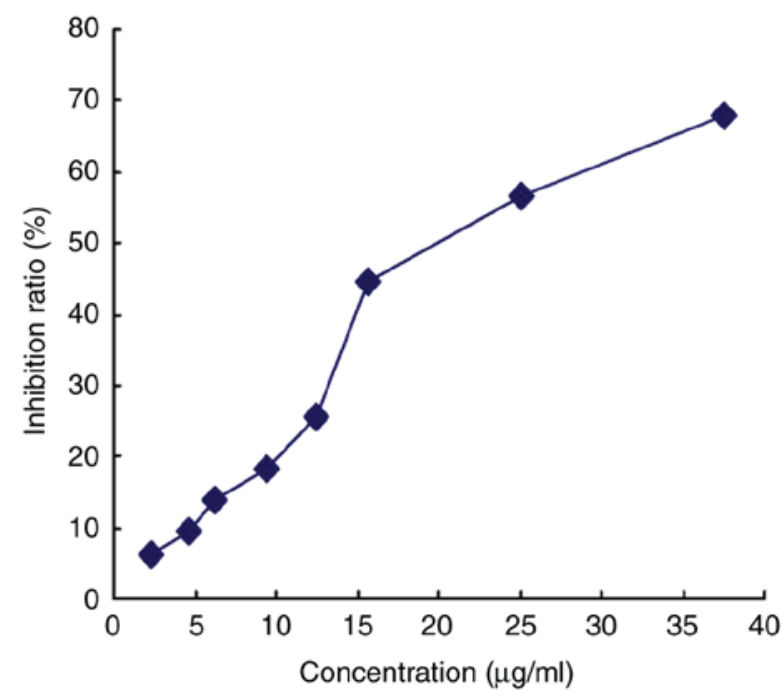

Figure 3. Anti-proliferative effect of paclitaxel on MCF-7 cells. Cultures were incubated with increasing paclitaxel concentrations, and proliferation was measured using the MTT Cell Proliferation Assay kit. Absorbance at $570 \mathrm{~nm}$ was determined using an enzyme-linked immunosorbent assay. $\mathrm{IC}_{10}$ and $\mathrm{IC}_{20}$ were determined to be, 5 and $10 \mu \mathrm{g} / \mathrm{ml}$, respectively. IC, inhibitory concentration.

Effects of mild hyperthermia combined with paclitaxel on MCF-7 growth. The effective killing concentration with paclitaxel was determined under the MCF-7 culture conditions using the MTT assay: The 10\% inhibitory concentration
$\left(\mathrm{IC}_{10}\right)$ and $20 \%$ inhibitory concentration $\left(\mathrm{IC}_{20}\right)$ were found to be 5 and $10 \mu \mathrm{g} / \mathrm{ml}$, respectively (Fig. 3). Cultures were treated with one of these doses of paclitaxel and incubated at $37^{\circ} \mathrm{C}$ for $24 \mathrm{~h}$. A proportion of cells appeared to shrink and become rounded, with decreased transparency, obvious contours and a dark brown color. A number of cells, likely apoptotic, floated in the culture medium. Over time, the number of apoptotic cells increased and the number of adherent, healthy-looking cells decreased.

Treatment with paclitaxel (5 or $10 \mu \mathrm{g} / \mathrm{ml})$ was combined with hyperthermia for $2 \mathrm{~h}$ at $40,40.5$ or $41^{\circ} \mathrm{C}$. Cultures were observed 24 or $48 \mathrm{~h}$ later. In cultures treated with $5 \mu \mathrm{g} / \mathrm{ml} \mathrm{pacli-}$ taxel and hyperthermia at $40^{\circ} \mathrm{C}$, cell apoptosis was relatively rare; in fact, it was similar to the level of apoptosis observed in cultures treated with $10 \mu \mathrm{g} / \mathrm{ml}$ paclitaxel alone. By contrast, a notably increased number of dead cells, as a result of either apoptosis or necrosis, were observed in cultures treated with 5 or $10 \mu \mathrm{g} / \mathrm{ml}$ of paclitaxel in combination with hyperthermia at 40.5 or $41^{\circ} \mathrm{C}$ for $2 \mathrm{~h}$. The number of dead cells increased over time following hyperthermia (Fig. 4).

Effects of mild hyperthermia combined with $5 \mu \mathrm{g} / \mathrm{ml}$ paclitaxel on the MCF-7 apoptotic ratio. To quantify the aforementioned visible differences in apoptosis observed, cultures were exposed to the $\mathrm{IC}_{10}$ paclitaxel dose of $5 \mu \mathrm{g} / \mathrm{ml}$, followed by exposure to $2 \mathrm{~h}$ of hyperthermia at different temperatures. The apoptotic ratio was measured at 24 or $48 \mathrm{~h}$ post-hyperthermia. 
A

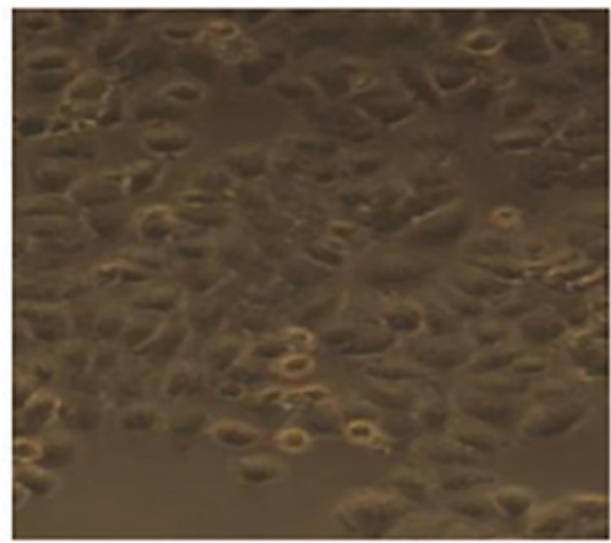

$37^{\circ} \mathrm{C} 24 \mathrm{~h}$

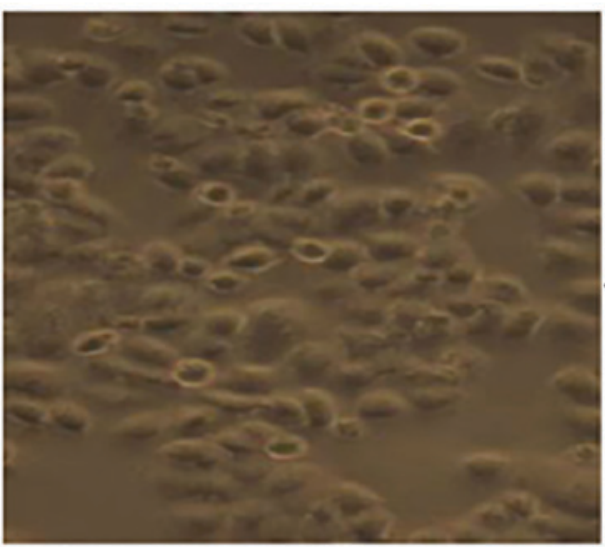

$40^{\circ} \mathrm{C} 24 \mathrm{~h}$

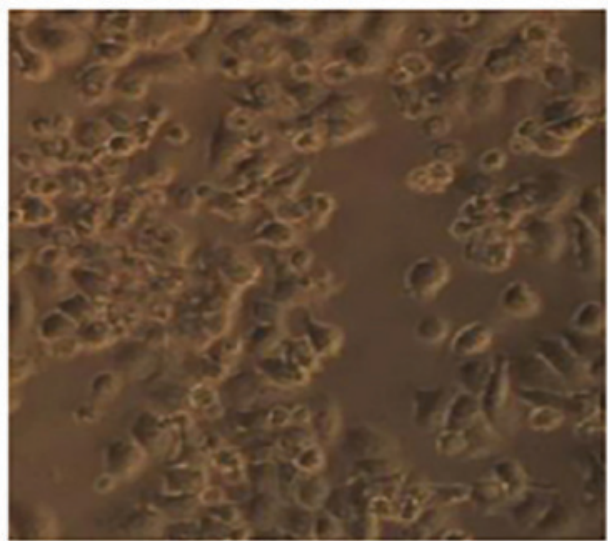

$40.5^{\circ} \mathrm{C} 24 \mathrm{~h}$

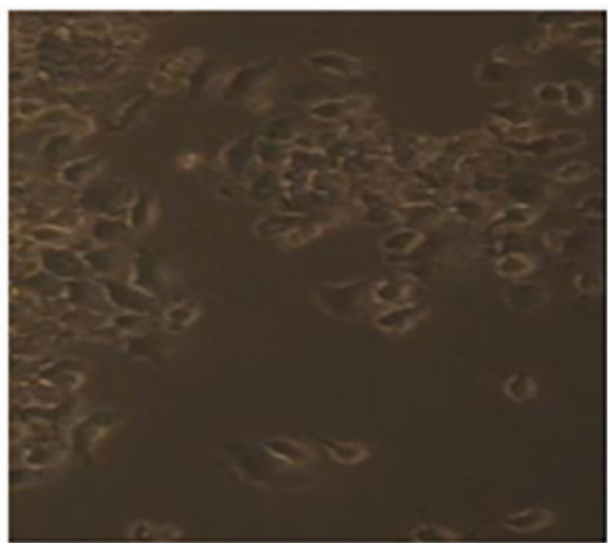

B

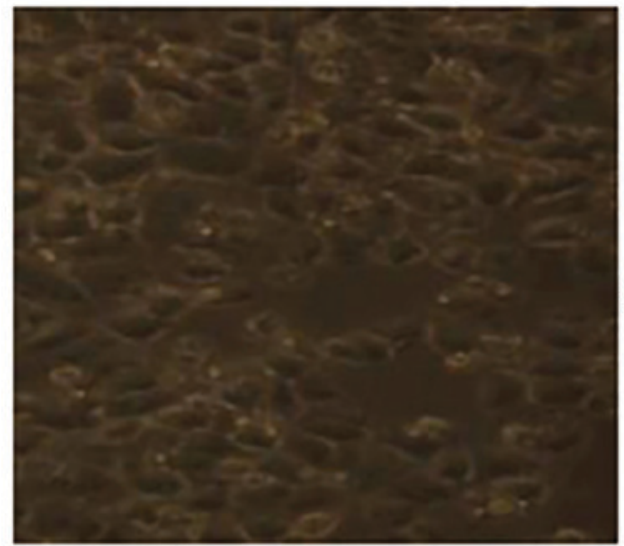

$37^{\circ} \mathrm{C} 48 \mathrm{~h}$

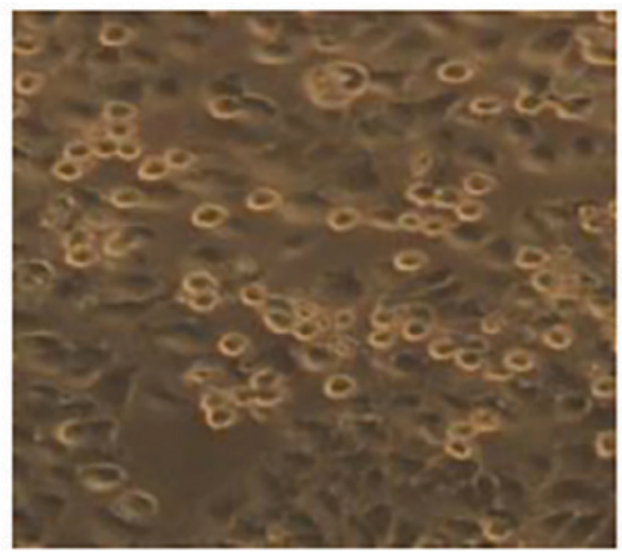

$40^{\circ} \mathrm{C} 48 \mathrm{~h}$

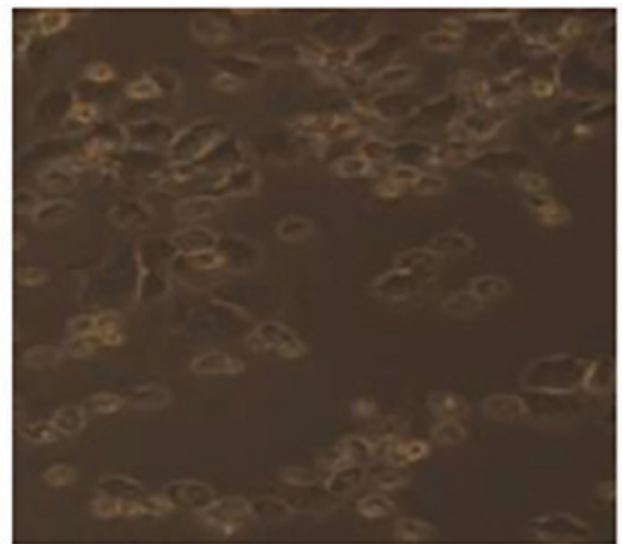

$40.5^{\circ} \mathrm{C} 48 \mathrm{~h}$

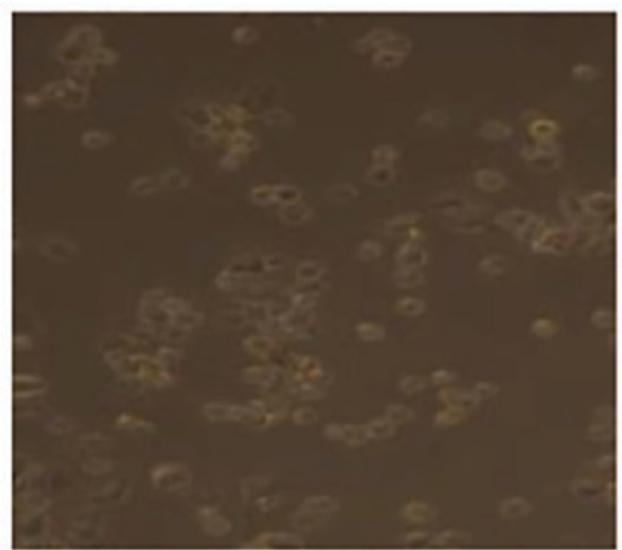

$41^{\circ} \mathrm{C} 48 \mathrm{~h}$ 
C
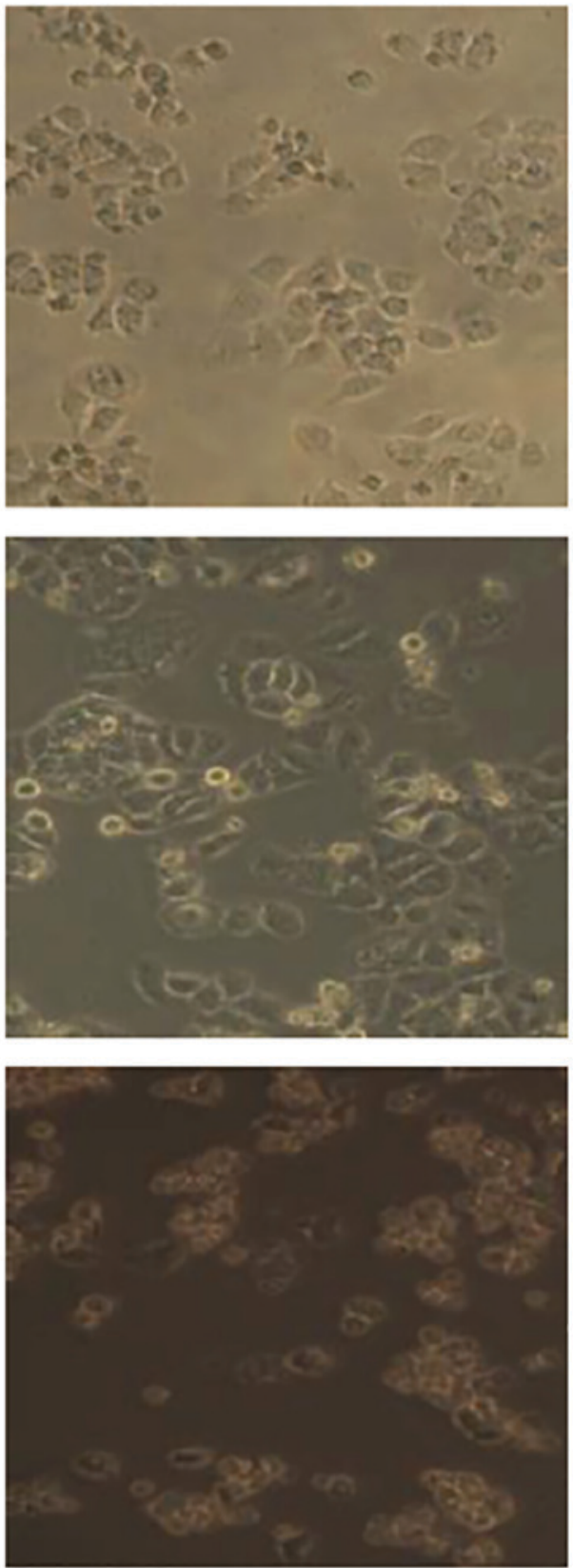

$40^{\circ} \mathrm{C} 24 \mathrm{~h}$

$40.5^{\circ} \mathrm{C} 24 \mathrm{~h}$

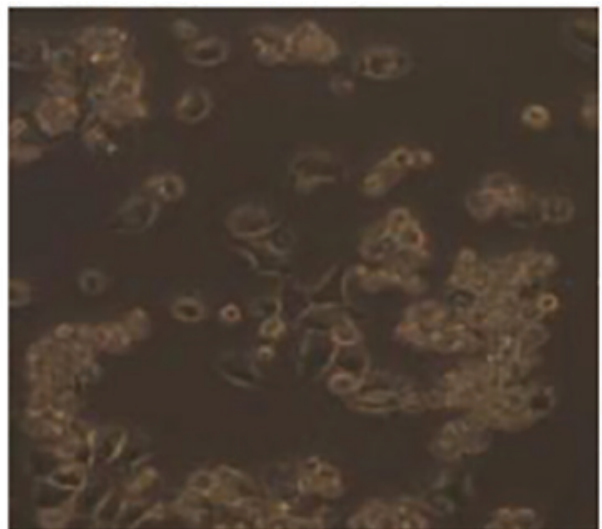

$37^{\circ} \mathrm{C} 24 \mathrm{~h}$
D

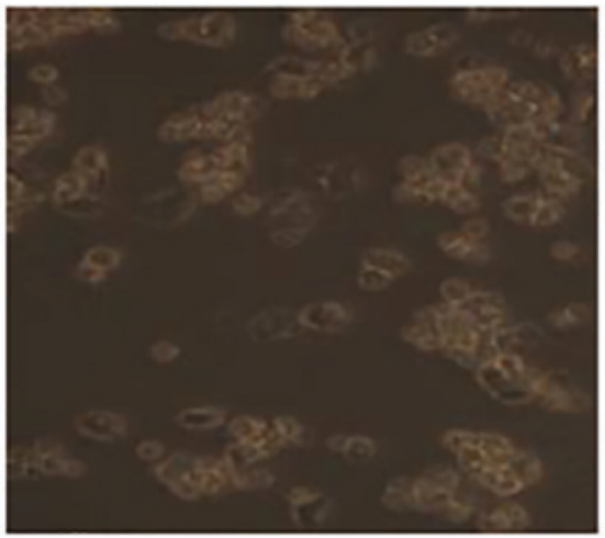

$37^{\circ} \mathrm{C} 48 \mathrm{~h}$

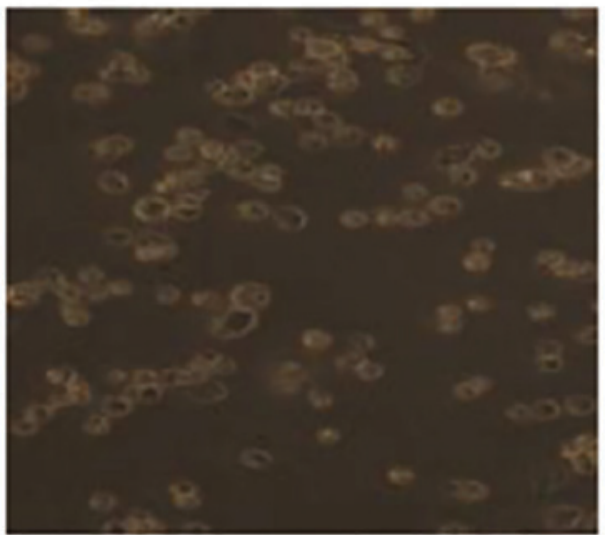

$40^{\circ} \mathrm{C} 48 \mathrm{~h}$

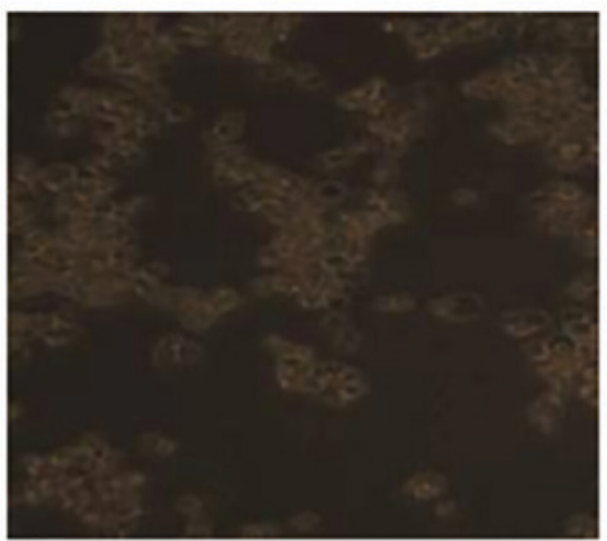

$40.5^{\circ} \mathrm{C} 48 \mathrm{~h}$

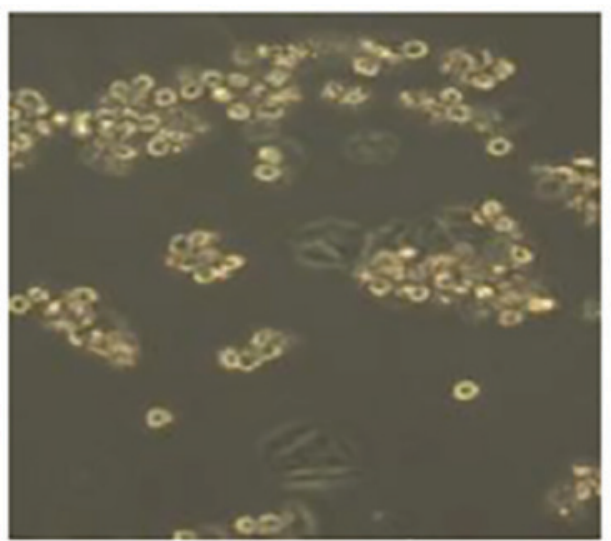

$41^{\circ} \mathrm{C} 48 \mathrm{~h}$

Figure 4. Continued. (C) MCF-7 cells $24 \mathrm{~h}$ post-treatment with $10 \mu \mathrm{g} / \mathrm{ml}$ of paclitaxel and exposure to mild hyperthermia. (D) MCF-7 cells $48 \mathrm{~h}$ post-treatment with $10 \mu \mathrm{g} / \mathrm{ml}$ of paclitaxel and exposure to mild hyperthermia. Cultures exposed to hyperthermia at $40^{\circ} \mathrm{C}$ displayed reduced apoptosis compared with cultures treated with $5 \mu \mathrm{g} / \mathrm{ml}$ paclitaxel alone, while cultures treated with hyperthermia at 40.5 or $41^{\circ} \mathrm{C}$ displayed greater numbers of dead cells (due to apoptosis or necrosis) compared with cultures treated with 5 or $10 \mu \mathrm{g} / \mathrm{ml}$ or paclitaxel alone. The numbers of dead cells increased with longer time after treatment. The images of $37^{\circ} \mathrm{C} 24 \mathrm{~h}$ and $37^{\circ} \mathrm{C} 48 \mathrm{~h}$ are the results of paclitaxel $(5$ or $10 \mu \mathrm{g} / \mathrm{ml})$ alone. Magnification, $\mathrm{x} 100$. 

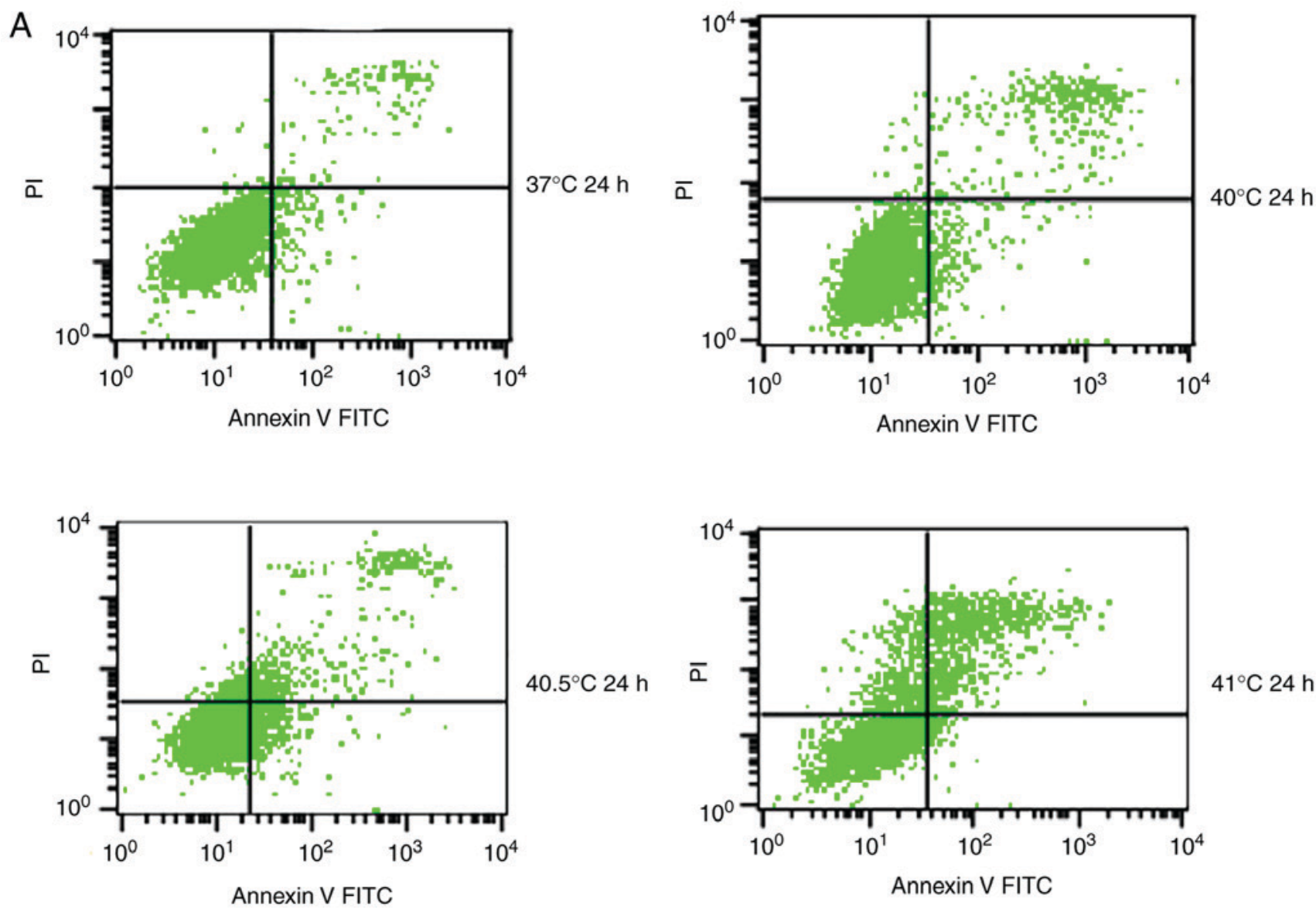

$41^{\circ} \mathrm{C} 24 \mathrm{~h}$
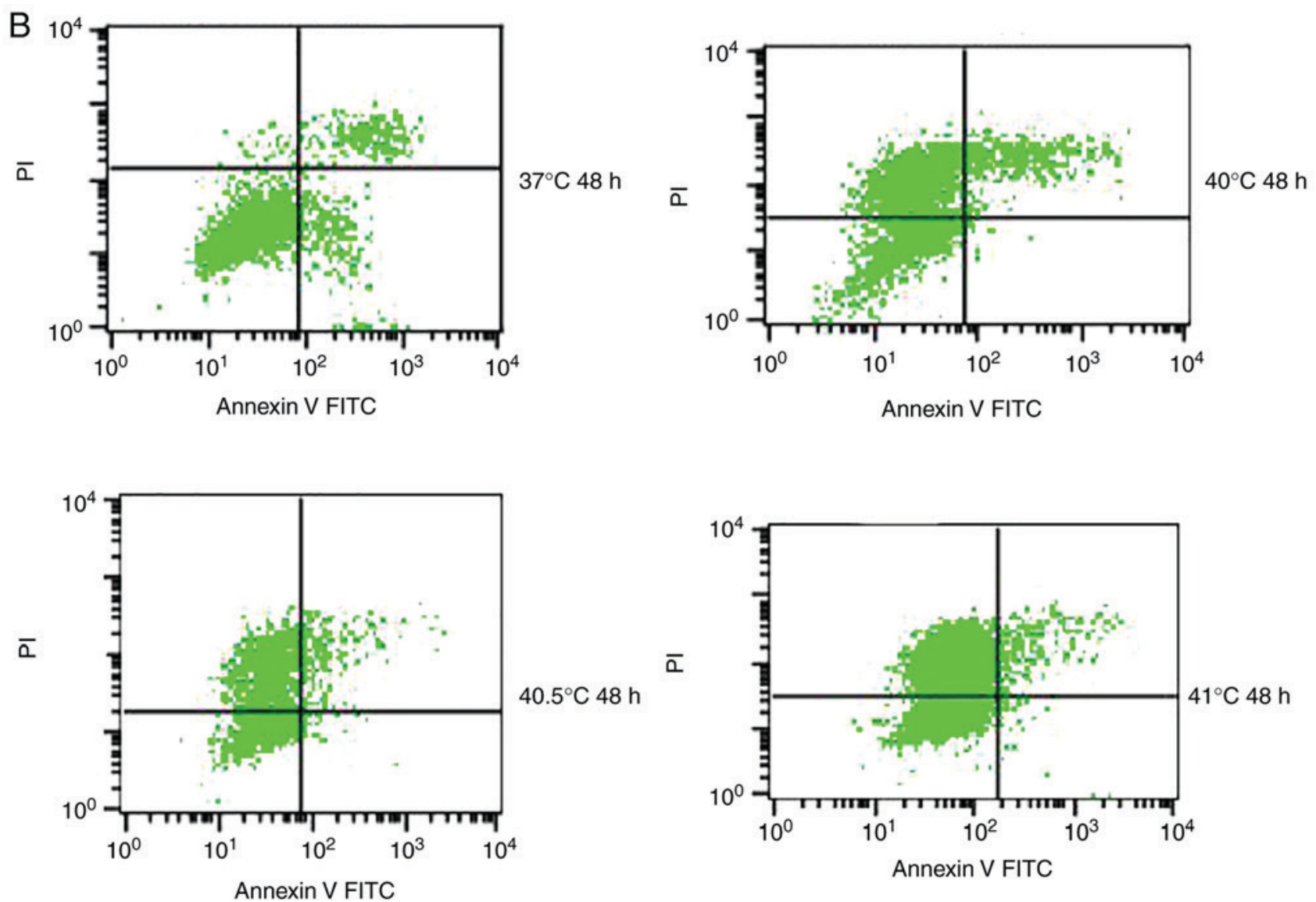

Figure 5. Effects of the combination of $5 \mu \mathrm{g} / \mathrm{ml}$ paclitaxel and mild hyperthermia on the apoptotic ratio of MCF-7 cells. Flow cytometry of MCF-7 cells using an Annexin V-FITC/PI cell apoptosis staining kit at (A) $24 \mathrm{~h}$ post-treatment or (B) $48 \mathrm{~h}$ post-treatment. 

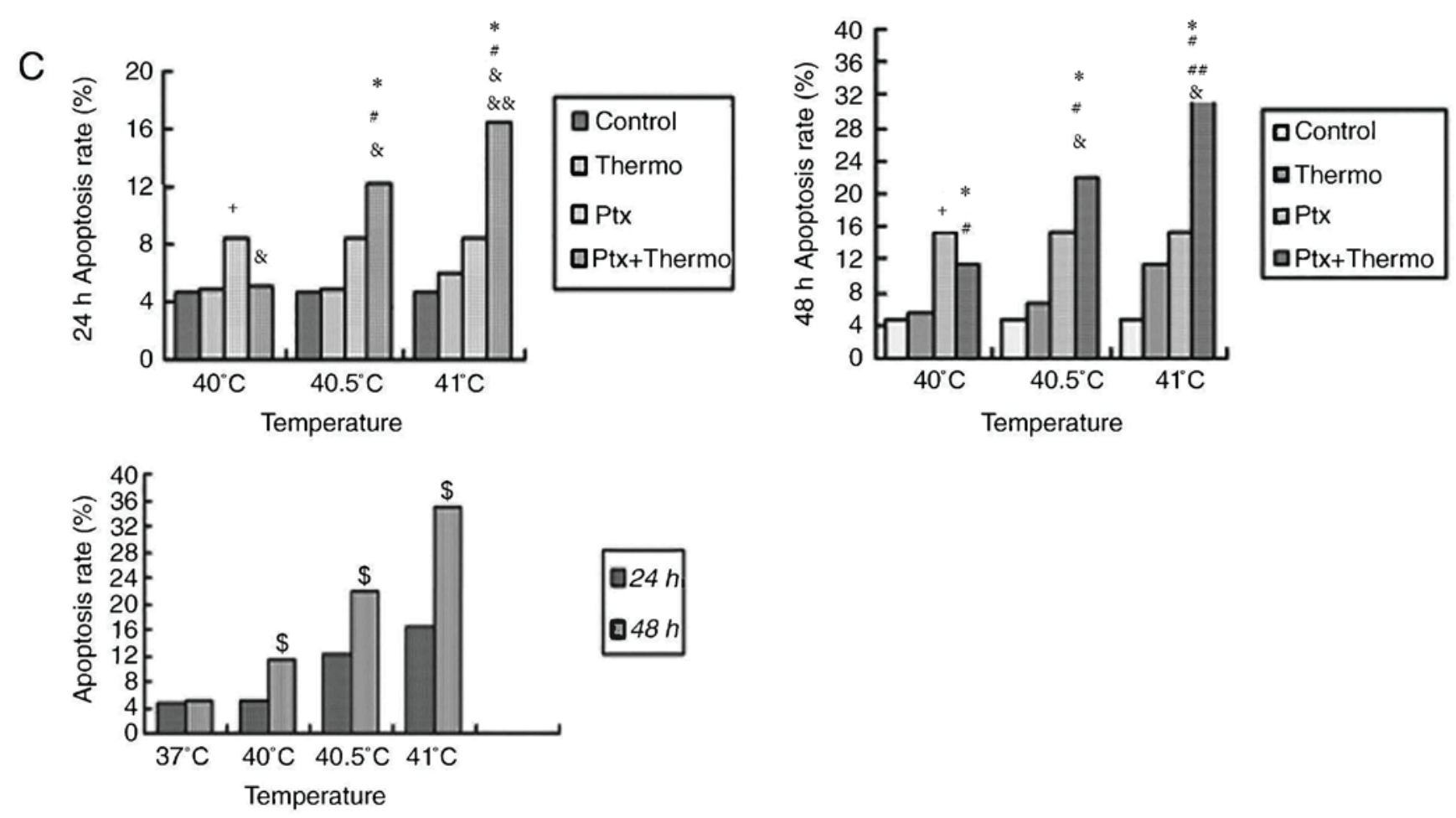

Figure 5. Continued. (C) Apoptotic ratios (\% apoptotic cells) at 24 and $48 \mathrm{~h}$ post-treatment at varying temperatures. ${ }^{*} \mathrm{P}<0.01$ vs. control; ${ }^{\#} \mathrm{P}<0.01$, vs. hyperthermia alone; ${ }^{\&} \mathrm{P}<0.05$ vs. chemotherapy alone; ${ }^{+} \mathrm{P}<0.05$ vs. combined therapy; ${ }^{\# \#} \mathrm{P}<0.01$ vs. $40.5^{\circ} \mathrm{C}$; ${ }^{\& \&} \mathrm{P}<0.05$ vs. $40.5^{\circ} \mathrm{C}$ combined therapy; ${ }^{\circledR} \mathrm{P}<0.05$ vs. $24 \mathrm{~h}$. FITC, fluorescein isothiocyanate; PI, propidium iodide; Ptx, paclitaxel.

At $24 \mathrm{~h}$ later, the apoptotic ratio was significantly higher in cultures treated with paclitaxel and hyperthermia at $40.5^{\circ} \mathrm{C}$ $(12.21 \pm 1.02 \%)$ compared with cultures treated with paclitaxel alone $(8.54 \pm 1.24 \%)$, or hyperthermia alone $(4.95 \pm 0.20 \%)$ $(\mathrm{P}<0.05)$. This indicated that paclitaxel and mild hyperthermia may act synergistically to induce apoptosis in MCF-7 cells.

The apoptotic ratio further increased, and the synergistic action became more notable with increasing hyperthermia temperatures (from $40.5^{\circ} \mathrm{C}$ to $\left.41^{\circ} \mathrm{C}\right)(\mathrm{P}<0.05$ or 0.01$)$, and with increasing lengths of time following hyperthermia (from 24 to $48 \mathrm{~h})(\mathrm{P}<0.05)$. Notably, a lower apoptotic ratio in cultures treated with paclitaxel and hyperthermia at $40^{\circ} \mathrm{C}$ was observed compared with cultures treated with paclitaxel alone. This suggests that low-temperature thermo-chemotherapy may enhance the activity of MCF-7 cells (Fig. 5).

Effects of mild hyperthermia combined with $10 \mu \mathrm{g} / \mathrm{ml}$ paclitaxel on the MCF-7 apoptotic ratio. Similar to the aforementioned experiments conducted with $5 \mu \mathrm{g} / \mathrm{ml}$ paclitaxel, cultures treated with $10 \mu \mathrm{g} / \mathrm{ml}$ of the drug and exposed to hyperthermia for $2 \mathrm{~h}$ at $40.5^{\circ} \mathrm{C}$ displayed a significantly higher apoptotic ratio at $24 \mathrm{~h}$ post-treatment $(25.88 \pm 1.21 \%)$, compared with cultures treated with paclitaxel alone $(16.87 \pm 2.59 \%)$, or hyperthermia alone $(4.95 \pm 0.20 \%)(\mathrm{P}<0.05)$. This provides further evidence to suggest that paclitaxel and hyperthermia may act synergistically.

This synergy became increasingly apparent at the higher hyperthermia temperature of $41^{\circ} \mathrm{C}$, since the apoptotic ratio was significantly higher $(\mathrm{P}<0.01)$. While the apoptotic ratio decreased between 24 and $48 \mathrm{~h}$ following hyperthermia, the number of necrotic cells increased $(\mathrm{P}<0.01)$, consistent with synergistic action.
Theresultsfrom the current study with thermo-chemotherapy at two different paclitaxel doses demonstrate that mild hyperthermia may induce anti-tumor effects by inducing cell apoptosis. The results further suggest that at higher paclitaxel doses and with increasing lengths of time following hyperthermia, necrosis may become a secondary mechanism helping to drive the anti-tumor effects of thermo-chemotherapy (Fig. 6).

\section{Discussion}

Over the last two decades, there have been continuous improvements in clinical hyperthermia technology; hence, exposure to hyperthermia has become a routine method for treating malignant tumors (22-24). Numerous basic and clinical studies have demonstrated that the combination of hyperthermia with radio- or chemotherapy may significantly improve tumor control rates and prolong survival (25-28). The majority of these studies have suggested that $42-45^{\circ} \mathrm{C}$ is the minimal effective temperature for hyperthermia induced by microwave or infrared radiation, or by incubation in a water bath (29-33). This poses a challenge for clinical implementation, as $41.8^{\circ} \mathrm{C}$ is considered the upper limit of whole-body temperature in humans, thus achieving temperatures of $42-45^{\circ} \mathrm{C}$ places a substantial burden on patients and equipment.

Achieving whole-body hyperthermia of $38-41^{\circ} \mathrm{C}$ may be technically and clinically more feasible (11-14), however various studies have reported conflicting results regarding whether hyperthermia at $40-41^{\circ} \mathrm{C}$ exerts anti-tumor effects. One study reported that $90 \mathrm{~min}$ of hyperthermia at $39-41^{\circ} \mathrm{C}$ activated cellular and humoral anti-tumor responses (34). In 

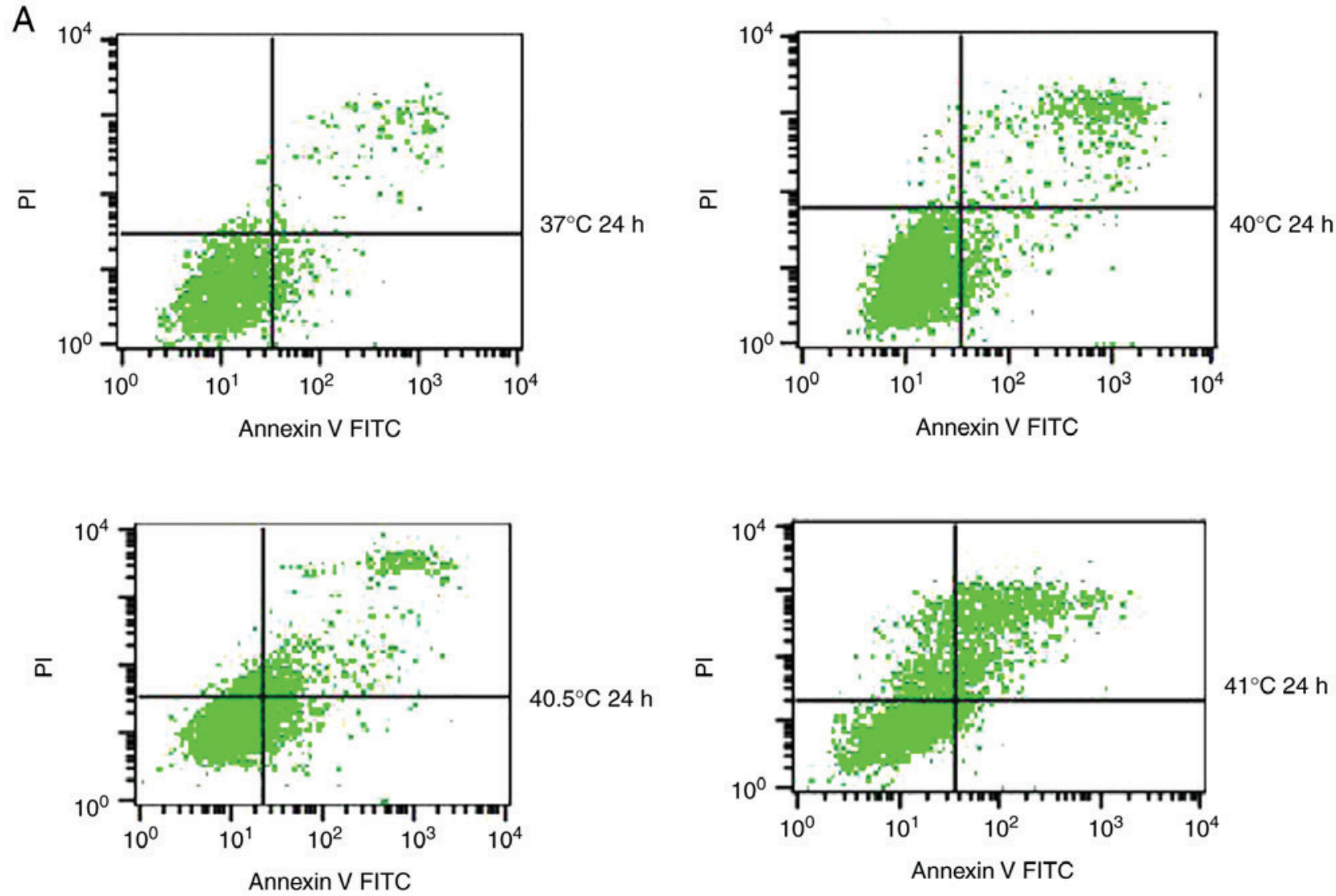

$41^{\circ} \mathrm{C} 24 \mathrm{~h}$
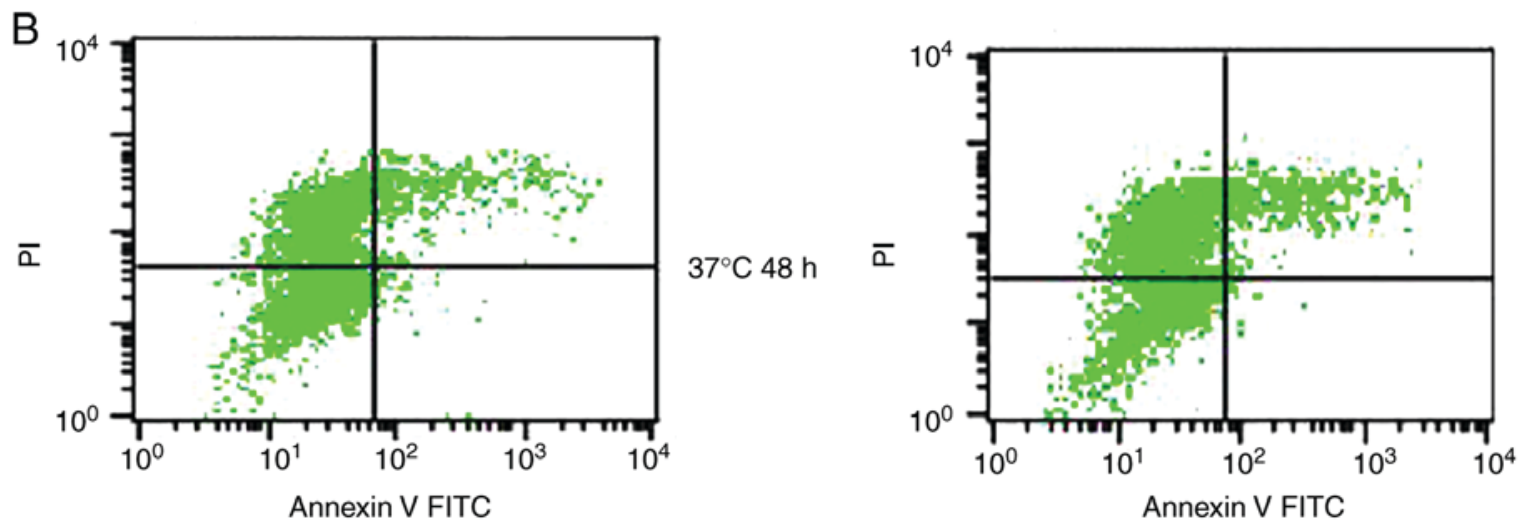

$40^{\circ} \mathrm{C} 48 \mathrm{~h}$
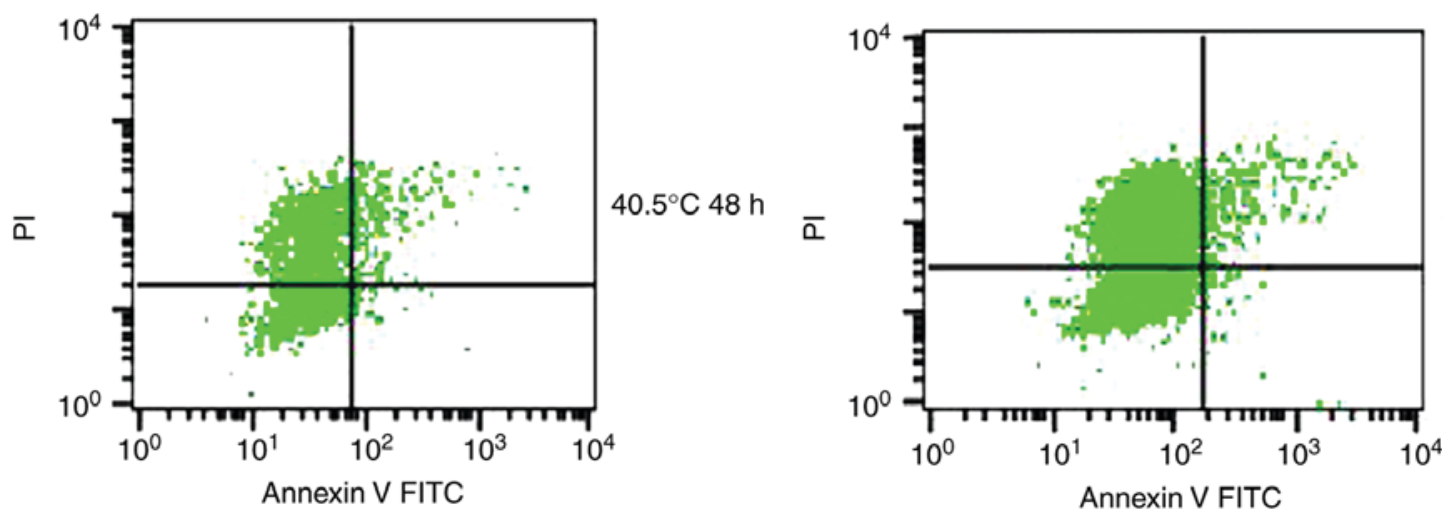

Figure 6. Effects of the combination of $10 \mu \mathrm{g} / \mathrm{ml}$ paclitaxel and mild hyperthermia on the apoptotic ratio of MCF-7 cells. Flow cytometry of MCF-7 cells using an Annexin V-FITC/PI cell apoptosis staining kit at (A) $24 \mathrm{~h}$ following treatment or (B) $48 \mathrm{~h}$ following treatment. 

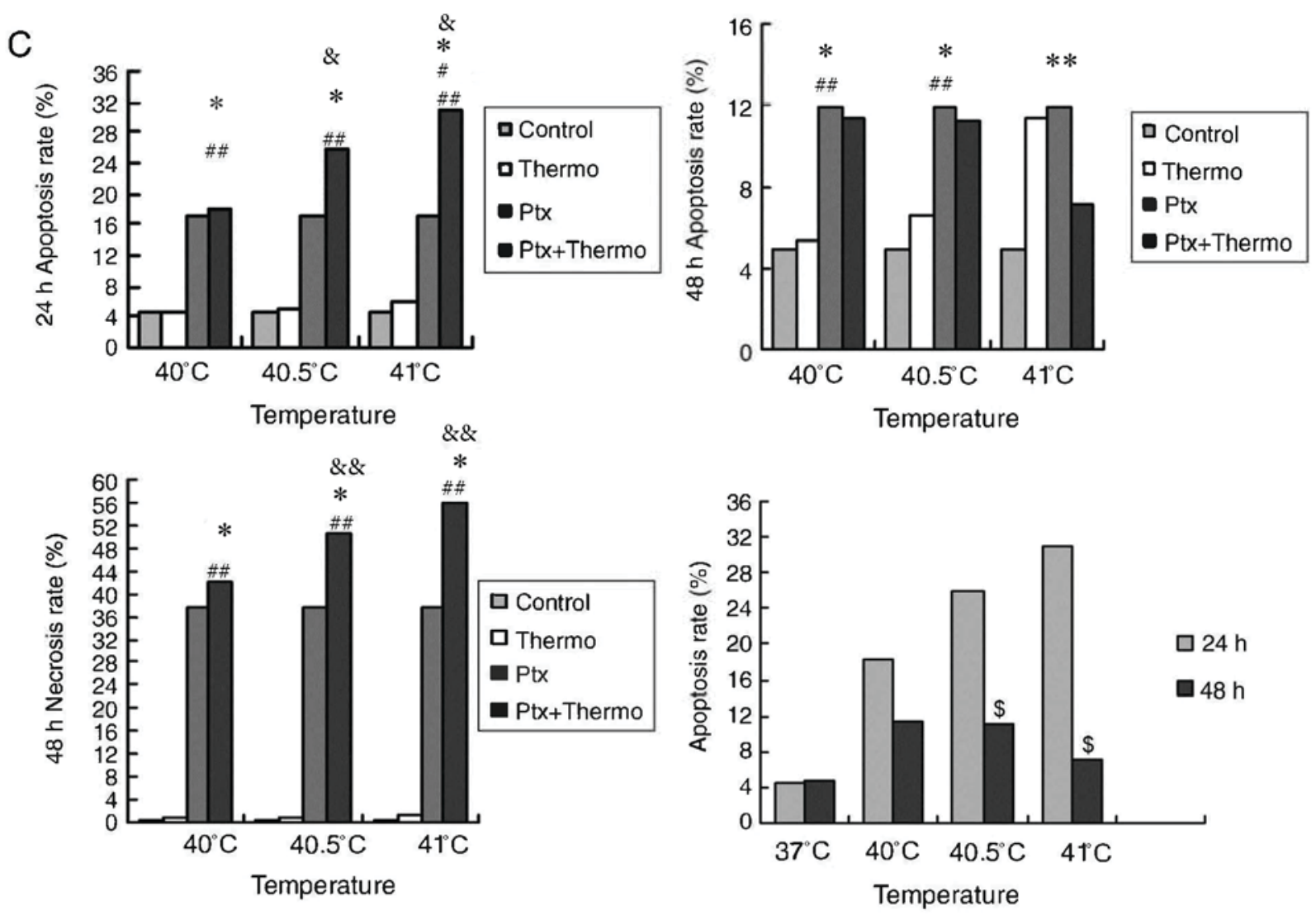

Figure 6. Continued. (C) Apoptotic ratios (\% of apoptotic cells) at 24 and $48 \mathrm{~h}$ post-treatment at varying temperatures. Necrotic ratios (\% of necrotic cells) at $48 \mathrm{~h}$ post-treatment at varying temperatures. ${ }^{~} \mathrm{P}<0.01$ vs. control; ${ }^{* *} \mathrm{P}<0.01$ vs. combined therapy; ${ }^{\prime} \mathrm{P}<0.01$ vs. $40.5^{\circ} \mathrm{C}$ combined therapy; ${ }^{\# \#} \mathrm{P}<0.01$ vs. hyper-

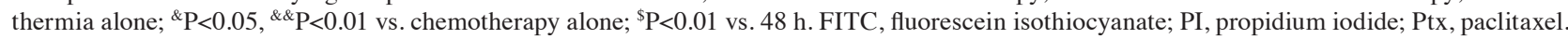

the present study, it was demonstrated that microwave-induced hyperthermia at $41^{\circ} \mathrm{C}$ lasting for $2 \mathrm{~h}$ induced apoptosis in the human breast cancer cell line MCF-7. Apoptosis was increased following hyperthermia at $41^{\circ} \mathrm{C}$ compared with $40^{\circ} \mathrm{C}$, and it was increased at $48 \mathrm{~h}$ following hyperthermia compared with at $24 \mathrm{~h}$ following hyperthermia. The results from the current study are consistent with previous work demonstrating that $2 \mathrm{~h}$ of hyperthermia at $41-44^{\circ} \mathrm{C}$ induced apoptosis in the leukemia cell lines HL-60, K562 and TF-1star at $96 \mathrm{~h}$ post-treatment, with temperatures of $43-44^{\circ} \mathrm{C}$ inducing the most obvious apoptotic morphology (35). These results suggest that $2 \mathrm{~h}$ of hyperthermia at $41^{\circ} \mathrm{C}$ may induce anti-tumor effects by inducing apoptosis. This justifies further preclinical studies into the potential of mild hyperthermia for treating cancer.

Although mild hyperthermia may be feasible in the clinic, available basic and clinical evidence suggests that hyperthermia on its own lacks the efficacy required for comprehensive treatment of malignant tumors $(36,37)$. Therefore, hyperthermia has generally been studied as an adjuvant to chemotherapy for improving the curative effect, while allowing lower chemotherapy doses to be used $(16,17,38-41)$. The minimum effective temperature for thermo-chemotherapy appears to be $40-43^{\circ} \mathrm{C}$. One study found that thermo-chemotherapy involving $2 \mathrm{~h}$ of hyperthermia at $41^{\circ} \mathrm{C}$ induced apoptosis in an increased number of tumor cells, and had more potent anti-tumor effects compared with hyperthermia or chemotherapy alone (42). Similarly, another study reported that combining $20 \mu \mathrm{mol} / 1$ docetaxel with $2 \mathrm{~h}$ of hyperthermia at $40-41^{\circ} \mathrm{C}$ induced apoptosis in an increased number tumor cells compared with chemotherapy alone (43). Additionally, it was reported that the apoptotic ratio increased with increasing hyperthermia temperature. However, the study did not compare thermo-chemotherapy with hyperthermia alone. In addition, few reports have examined the combination of low-dose chemotherapy and microwave-induced hyperthermia at temperatures $<41^{\circ} \mathrm{C}$.

In the present study, it was demonstrated that the combination of $5 \mu \mathrm{g} / \mathrm{ml}$ paclitaxel and $2 \mathrm{~h}$ of hyperthermia at $40.5^{\circ} \mathrm{C}$ induced apoptosis in MCF-7 cells at $24 \mathrm{~h}$ post-treatment, and that this pro-apoptotic induction was greater compared with either therapy alone, indicating synergistic action. This synergistic effect became even more apparent when the time following hyperthermia was increased to $48 \mathrm{~h}$ compared with $24 \mathrm{~h}$, and when the hyperthermia temperature was $41^{\circ} \mathrm{C}$ compared with 40 or $40.5^{\circ} \mathrm{C}$. Therefore, the results from the current study suggest that paclitaxel and mild hyperthermia at temperatures as low as $40.5^{\circ} \mathrm{C}$ may induce apoptosis in tumor cells and interact synergistically in order to kill tumor cells.

Notably, it was reported that the combination of 5 or $10 \mu \mathrm{g} / \mathrm{ml}$ paclitaxel and $2 \mathrm{~h}$ of hyperthermia at $40^{\circ} \mathrm{C}$ was associated with a significantly smaller apoptotic ratio at 24 or $48 \mathrm{~h}$ following treatment, compared with paclitaxel treatment alone. Cells treated with the combination therapy demonstrated a proliferative trend. These results are consistent with a previous study that reported that thermo-chemotherapy involving hyperthermia at $39-40^{\circ} \mathrm{C}$ increased tumor cell activity (42). 
The results from the current study suggest that paclitaxel dosage and hyperthermia temperature require careful optimization in order to enhance the cytotoxicity of paclitaxel, and avoid the promotion of tumor cell growth.

The cytotoxic mechanism of the combination of paclitaxel and mild hyperthermia may involve apoptosis and necrosis. Treating MCF-7 cultures with $10 \mu \mathrm{g} / \mathrm{ml}$ paclitaxel and $2 \mathrm{~h}$ of hyperthermia at 40.5 or $41^{\circ} \mathrm{C}$ induced tumor cell apoptosis $24 \mathrm{~h}$ post-treatment, in a synergistic fashion. At $48 \mathrm{~h}$ following treatment, the extent of necrosis was greater compared with that of apoptosis. The extent of necrosis relative to apoptosis was even greater when the hyperthermia temperature was $41^{\circ} \mathrm{C}$. These results are concordant with previous work (44), and may reflect an enhancement of paclitaxel cytotoxicity at higher temperatures. With increased durations of hyperthermia exposure, the cytotoxic effect of paclitaxel was stronger, and it was demonstrated that cell necrosis prevailed over apoptosis. However, results from Michalakis et al (44) suggested that hyperthermia (at 41.5 or $43^{\circ} \mathrm{C}$ ) exerted a cytostatic effect to all cell lines, including the human breast cell MCF-7, the ovarian SKOV-3 cell line and the hepatocarcinoma HepG2 cell line. The results of the present study suggested that mild hyperthermia $<41.5^{\circ} \mathrm{C}$ may induce apoptosis in the human breast cell line MCF-7, and the combination of mild hyperthermia at $40.5-41^{\circ} \mathrm{C}$ with low-dose paclitaxel at 5 or $10 \mu \mathrm{g} / \mathrm{ml}$ (IC10/IC20) may exert synergistic anti-tumor effects. This has previously been reported for various other chemotherapy drugs $(45,46)$. In conclusion, the present study reports that mild hyperthermia $\left(41^{\circ} \mathrm{C}\right)$ alone may induce apoptosis in the human breast cancer cell line MCF-7, and that this effect is enhanced with increasing lengths of time following hyperthermia. The results further suggest that the combination of mild hyperthermia at $40.5-41^{\circ} \mathrm{C}$ with low-dose paclitaxel may exert synergistic anti-tumor effects, which are enhanced at higher hyperthermia temperatures and with longer periods following hyperthermia.

\section{Acknowledgements}

Not applicable.

\section{Funding}

The present study was supported by the Medication and Health Care Research Program of Guangxi (grant no. S201418-03 and S201634), the Guangxi Natural Science Foundation (grant no. 2017GXNSFAA198103), the Key Planning DevelopmentResearch Program of Guangxi (grant no.guikeAB16380215) and the Health and Family Planning Commission Project of Guangxi (grant no. Z20170452).

\section{Availability of data and materials}

The datasets used and/or analyzed during the present study are available from the corresponding author on reasonable request.

\section{Authors' contributions}

SNL conceptualised the study, analysed and interpreted the data and was involved in drafting the manuscript.SNL also gave final approval of the version to be published. XLL and YQL designed the study and revised the manuscript. XHH, ZHL, YL, RL, YMZ, QL contributed the conception design and editing of the manuscript. All authors read and approved the final manuscript.

\section{Ethics approval and consent to participate}

Not applicable.

\section{Patient consent for publication}

Not applicable.

\section{Competing interests}

The authors declare that they have no competing interests.

\section{References}

1. Zeichner SB, Ambros T, Zaravinos J, Montero AJ, Mahtani RL, Ahn ER, Mani A, Markward NJ and Vogel CL: Defining the survival benchmark for breast cancer patients with systemic relapse. Breast Cancer (Auck1) 9: 9-17, 2015.

2. Siegel RL, Miller KD and Jemal A: Cancer statistics, 2015. CA Cancer J Clin 65: 5-29, 2015.

3. Taatjes DJ, Fenick DJ and Koch TH: Nuclear targeting and nuclear retention of anthracycline-formaldehyde conjugates implicates DNA covalent bonding in the cytotoxic mechanism of anthracyclines. Chem Res Toxicol 12: 588-596, 1999.

4. Carrick S, Parker S, Thornton CE, Ghersi D, Simes J and Wilcken N: Single agent versus combination chemotherapy for metastatic breast cancer. Cochrane Database Syst Rev CD003372, 2009.

5. O'Brien ME, Wigler N, Inbar M, Rosso R, Grischke E, Santoro A, Catane R, Kieback DG, Tomczak P, Ackland SP, et al: Reduced cardiotoxicity and comparable efficacy in a phase III trial of pegylated liposomal doxorubicin $\mathrm{HCl}$ (CAELYX/Doxil) versus conventional doxorubicin for first-line treatment of metastatic breast cancer. Ann Oncol 15: 440-449, 2004.

6. Keller AM, Mennel RG, Georgoulias VA, Nabholtz JM, Erazo A, Lluch A, Vogel CL, Kaufmann M, von Minckwitz G, Henderson IC, et al: Randomized phase III trial of pegylated liposomal doxorubicin versus vinorelbine or mitomycin $\mathrm{C}$ plus vinblastine in women with taxane-refractory advanced breast cancer. J Clin Oncol 22: 3893-3901, 2004.

7. Piccart-Gebhart MJ, Burzykowski T, Buyse M, Sledge G, Carmichael J, Luck HJ, Mackey JR, Nabholtz JM, Paridaens R, Biganzoli L, et al: Taxanes alone or in combination with anthracyclines as first-line therapy of patients with metastatic breast cancer. J Clin Oncol 26: 1980-1986, 2008.

8. Buzdar AU, Singletary SE, Theriault RL, Booser DJ, Valero V, Ibrahim N, Smith TL, Asmar L, Frye D, Manuel N, et al: Prospective evaluation of paclitaxel versus combination chemotherapy with fluorouracil, doxorubicin, and cyclophosphamide as neoadjuvant therapy in patients with operable breast cancer. J Clin Oncol 17: 3412-3417, 1999.

9. Shapiro CL and Recht A: Side effects of adjuvant treatment of breast cancer. N Engl J Med 344: 1997-2008, 2001.

10. Klostergaard J, Leroux ME, Auzenne E, Khodadadian M, Spohn W, Wu JY and Donato NJ: Hyperthermia engages the intrinsic apoptotic pathway by enhancing upstream caspase activation to overcome apoptotic resistance in MCF-7 breast adenocarcinoma cells. J Cell Biochem 98: 356-369, 2006.

11. Mohamed F, Marchettini P, Stuart OA, Urano M and Sugarbaker PH: Thermal enhancement of new chemotherapeutic agents at moderate hyperthermia. Ann Surg Oncol 10: 463-468, 2003.

12. Westermann AM, Grosen EA, Katschinski DM, Jager D, Rietbroek R, Schink JC, Tiggelaar CL, Jager E, Zum Vorde sive Vörding P, Neuman A, et al: A pilot study of whole body hyperthermia and carboplatin in platinum-resistant ovarian cancer. Eur J Cancer 37: 1111-1117, 2001. 
13. Ressel A, Weiss C and Feyerabend T: Tumor oxygenation after radiotherapy, chemotherapy, and/or hyperthermia predicts tumor free survival. Int J Radiat Oncol Biol Phys 49: 1119-1125, 2001.

14. Burd R, Dziedzic TS, Xu Y, Caligiuri MA, Subjeck JR and Repasky EA: Tumor cell apoptosis, lymphocyte recruitment and tumor vascular changes are induced by low temperature, long duration (fever-like) whole body hyperthermia. J Cell Physiol 177: 137-147, 1998.

15. Peer AJ, Grimm MJ, Zynda ER and Repasky EA: Diverse immune mechanisms may contribute to the survival benefit seen in cancer patients receiving hyperthermia. Immunol Res 46: $137-154,2010$

16. Issels RD, Schlemmer M and Lindner LH: The role of hyperthermia in combined treatment in the management of soft tissue sarcoma. Curr Oncol Rep 8: 305-309, 2006

17. Jones EL, Oleson JR, Prosnitz LR, Samulski TV, Vujaskovic Z, Yu D, Sanders LL and Dewhirst MW: Randomized trial of hyperthermia and radiation for superficial tumors. J Clin Oncol 23 : 3079-3085, 2005.

18. Westermann AM,Jones EL,Schem BC, vander Steen-Banasik EM, Koper P, Mella O, Uitterhoeve AL, de Wit R, van der Velden J, Burger C, et al: First results of triple-modality treatment combining radiotherapy, chemotherapy, and hyperthermia for the treatment of patients with stage IIB, III, and IVA cervical carcinoma. Cancer 104: 763-770, 2005.

19. El-Kareh AW and Secomb TW: A theoretical model for intraperitoneal delivery of cisplatin and the effect of hyperthermia on drug penetration distance. Neoplasia 6: 117-127, 2004.

20. Frey B, Weiss EM, Rubner Y, Wunderlich R, Ott OJ, Sauer R, Fietkau R and Gaipl US: Old and new facts about hyperthermia-induced modulations of the immune system. Int J Hyperthermia 28: 528-542, 2012.

21. Yamada Y, Itoh Y, Aoki S, Nakamura K, Taki T, Naruse K, Tobiume M, Zennami K, Katsuda R, Kato Y, et al: Preliminary results of M-VAC chemotherapy combined with mild hyperthermia, a new therapeutic strategy for advanced or metastatic transitional cell carcinoma of the urothelium. Cancer Chemother Pharmacol 64: 1079-1083, 2009.

22. Yellin A, Simansky DA, Paley M and Refaely Y: Hyperthermic pleural perfusion with cisplatin: Early clinical experience. Cancer 92: 2197-2203, 2001.

23. Mujoomdar AA and Sugarbaker DJ: Hyperthermic chemoperfusion for the treatment of malignant pleural mesothelioma. Semin Thorac Cardiovasc Surg. Winter 20: 298-304, 2008.

24. Murthy $R$, Honavar SG, Naik $M$ and Reddy VA: Thermochemotherapy in hereditary retinoblastoma. $\mathrm{Br}$ J Ophthalmol 87: 1432, 2003.

25. Jin Y, Ma X, Zhang S, Meng H, Xu M, Yang X, Xu W and Tian J: A tantalum oxide-based core/shell nanoparticle for triple-modality image-guided chemo-thermal synergetic therapy of esophageal carcinoma. Cancer Lett 397: 61-71, 2017.

26. Huilgol NG: A retrospective analysis of patients with head and neck cancer treated with radiation, hyperthermia, and cetuximab: A brief report of outcome. J Cancer Res Ther 12: 1164-1166, 2016.

27. Tao Y, Guo Y, Liu W, Zhang J, Li X, Shen L, Ru Y, Xue Y, Zheng J, Liu X, et al: AKT inhibitor suppresses hyperthermia-induced Ndrg2 phosphorylation in gastric cancer cells. Braz J Med Biol Res 46: 394-404, 2013.

28. Kong G, Braun RD and Dewhirst MW: Characterization of the effect of hyperthermia on nanoparticle extravasation from tumor vasculature. Cancer Res 61: 3027-3032, 2001.

29. Xie X, Shao X, Gao F, Jin H, Zhou J, Du L, Zhang Y, Ouyang W, Wang X, Zhao L, et al: Effect of hyperthermia on invasion ability and TGF-beta1 expression of breast carcinoma MCF-7 cells. Oncol Rep 25: 1573-1579, 2011.

30. Kanaya Y, Doihara H, Shiroma K, Ogasawara Y and Date H: Effect of combined therapy with the antiestrogen agent toremifene and local hyperthermia on breast cancer cells implanted in nude mice. Surg Today 38: 911-920, 2008.

31. Sawaji Y, Sato T, Takeuchi A,Hirata M and Ito A: Anti-angiogenic action of hyperthermia by suppressing gene expression and production of tumour-derived vascular endothelial growth factor in vivo and in vitro. Br J Cancer 86: 1597-1603, 2002.
32. Saga T, Sakahara H, Nakamoto $Y$, Sato N, Ishimori T, Mamede M, Kobayashi H, Masunaga S, Sasai K, Kuroki M and Konishi J: Enhancement of the therapeutic outcome of radio-immunotherapy by combination with whole-body mild hyperthermia. Eur J Cancer 37: 1429-1434, 2001.

33. Rong Y and Mack P: Apoptosis induced by hyperthermia in Dunn osteosarcoma cell line in vitro. Int J Hyperthermia 16: 19-27, 2000.

34. Huang YH, Haegerstrand A and Frostegard J: Effects of in vitro hyperthermia on proliferative responses and lymphocyte activity. Clin Exp Immunol 103: 61-66, 1996.

35. Deezagi A, Manteghi S, Khosravani P, Vaseli-Hagh N and Soheili ZS: Induced apoptosis by mild hyperthermia occurs via telomerase inhibition on the three human myeloid leukemia cell lines: TF-1, K562, and HL-60. Leuk Lymphoma 50: 1519-1527, 2009.

36. Canbay E, Ishibashi H, Sako S, Mizumoto A, Hirano M, Ichinose M, Takao N and Yonemura Y: Preoperative carcinoembryonic antigen level predicts prognosis in patients with pseudomyxoma peritonei treated with cytoreductive surgery and hyperthermic intraperitoneal chemotherapy. World J Surg 37: 1271-1276, 2013.

37. Robins HI and Longo W: Whole body hyperthermia: Simple complexities. Intensive Care Med 25: 898-900, 1999.

38. Jiang Z, Yan W, Ming J and Yu Y: Docetaxel weekly regimen in conjunction with RF hyperthermia for pretreated locally advanced non-small cell lung cancer: A preliminary study. BMC Cancer 7: 189, 2007.

39. Hildebrandt B, Drager J, Kerner T, Deja M, Loffel J, Stroszczynski C, Ahlers O, Felix R, Riess H and Wust P: Whole-body hyperthermia in the scope of von Ardenne's systemic cancer multistep therapy (sCMT) combined with chemotherapy in patients with metastatic colorectal cancer: A phase I/II study. Int J Hyperthermia 20: 317-333, 2004

40. Takahashi I, Emi Y, Hasuda S, Kakeji Y, Maehara Y and Sugimachi K: Clinical application of hyperthermia combined with anticancer drugs for the treatment of solid tumors. Surgery 131: S78-S84, 2002.

41. Wendtner C, Abdel-Rahman S, Baumert J, Falk MH, Krych M, Santl M, Hiddemann W and Issels RD: Treatment of primary, recurrent or inadequately resected high-risk soft-tissue sarcomas (STS) of adults: Results of a phase II pilot study (RHT-95) of neoadjuvant chemotherapy combined with regional hyperthermia. Eur J Cancer 37: 1609-1616, 2001.

42. Kappel M, Stadeager C, Tvede N, Galbo H and Pedersen BK: Effects of in vivo hyperthermia on natural killer cell activity, in vitro proliferative responses and blood mononuclear cell subpopulations. Clin Exp Immunol 84: 175-180, 1991.

43. Lv F, Yu Y, Zhang B, Liang D, Li ZM and You W: Inhibitory effects of mild hyperthermia plus docetaxel therapy on ER(+/-) breast cancer cells and action mechanisms. J Huazhong Univ Sci Technolog Med Sci 33: 870-876, 2013.

44. Michalakis J, Georgatos SD, de Bree E, Polioudaki H, Romanos J, Georgoulias V, Tsiftsis DD and Theodoropoulos PA: Short-term exposure of cancer cells to micromolar doses of paclitaxel, with or without hyperthermia, induces long-term inhibition of cell proliferation and cell death in vitro. Ann Surg Oncol 14: 1220-1228, 2007.

45. Michalakis J, Georgatos SD, Romanos J, Koutala H, Georgoulias V, Tsiftsis D and Theodoropoulos PA: Micromolar taxol, with or without hyperthermia, induces mitotic catastrophe and cell necrosis in HeLa cells. Cancer Chemother Pharmacol 56: 615-622, 2005.

46. Urano M, Kuroda M and Nishimura Y: For the clinical application of thermochemotherapy given at mild temperatures. Int J Hyperthermia 15: 79-107, 1999. 